San Jose State University

SJSU ScholarWorks

Master's Theses

Master's Theses and Graduate Research

1990

\title{
The Italian Socialist Party (1892-1925) constitutional or revolutionary action
}

Eugene Michael Franco

San Jose State University

Follow this and additional works at: https://scholarworks.sjsu.edu/etd_theses

\section{Recommended Citation}

Franco, Eugene Michael, "The Italian Socialist Party (1892-1925) constitutional or revolutionary action" (1990). Master's Theses. 45.

DOI: https://doi.org/10.31979/etd.b8hz-zsqw

https://scholarworks.sjsu.edu/etd_theses/45

This Thesis is brought to you for free and open access by the Master's Theses and Graduate Research at SJSU ScholarWorks. It has been accepted for inclusion in Master's Theses by an authorized administrator of SJSU ScholarWorks. For more information, please contact scholarworks@sjsu.edu. 


\section{INFORMATION TO USERS}

The most advanced technology has been used to photograph and reproduce this manuscript from the microfilm master. UMI films the text directly from the original or copy submitted. Thus, some thesis and dissertation copies are in typewriter face, while others may be from any type of computer printer.

The quality of this reproduction is dependent upon the quality of the copy submitted. Broken or indistinct print, colored or poor quality illustrations and photographs, print bleedthrough, substandard margins, and improper alignment can adversely affect reproduction.

In the unlikely event that the author did not send UMI a complete manuscript and there are missing pages, these will be noted. Also, if unauthorized copyright material had to be removed, a note will indicate the deletion.

Oversize materials (e.g., maps, drawings, charts) are reproduced by sectioning the original, beginning at the upper left-hand corner and continuing from left to right in equal sections with small overlaps. Each original is also photographed in one exposure and is included in reduced form at the back of the book.

Photographs included in the original manuscript have been reproduced xerographically in this copy. Higher quality 6" x 9" black and white photographic prints are available for any photographs or illustrations appearing in this copy for an additional charge. Contact UMI directly to order.

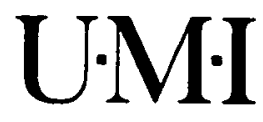

University Microfilms International

A Bell \& Howell Information Company

300 North Zeeb Road, Ann Arbor, Ml 48106-1346 USA

$313 / 761-4700 \quad 800 / 521-0600$ 
- 
The Italian Socialist Party (1892-1925): Constitutional or revolutionary action

Franco, Eugene Michael, M.A.

San Jose State University, 1990 


\title{
THE ITALIAN SOCIALIST PARTY (1892-1925): CONSTITUTIONAL OR REVOLUTIONARY ACTION
}

\author{
A Thesis \\ Presented to \\ The Faculty of the Department of Political Sclence \\ San Jose State Unlverslty
}

In Partial Fulfillment

of the Requirements for the Degree

Master of Arts

a..............

By

Eugene Michael Franco

December, 1990 
APPROVED FOR THE DEPARTMENT OF POLITICAL SCIENCE
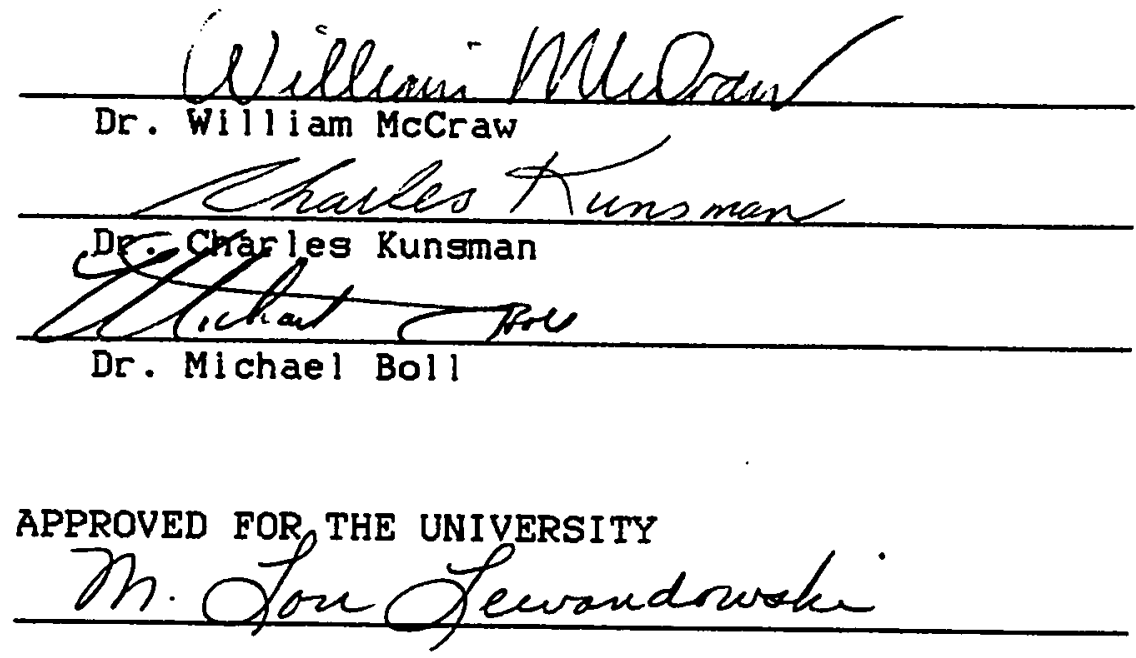


\section{ABSTRACT \\ THE ITALIAN SOCIALIST PARTY (1892-1925): CONSTITUTIONAL OR REVOLUTIONARY ACTION}

by Eugene Michael Franco

The thesls of this paper is that, glven the partlcular Itallan economlc, soclal, and historlcal conditions, the Itallan Soclallst movement did not develop to the same extent as other European Sociallst movements, due to the divisions which lead to distinct constitutional and revolutionary partles. The Itallan Sociallst Party (PSI) is caught in the dilemma of constltutionalism versus revolution. This theory prevents the Soclalist Party from taking effective actlon in the larger arena of Italian politlcs, but, nevertheless, the majorlty of its members still find no contradiction in its principles.

The maln part of thls thesls will discuss the development of the Itallan Soclallst Party from lts organization in 1892 to its suppression in 1925, taking up the stages of uniflcation, struggle for legitimacy, conflict between constltutionalism and revolution in political action, and the confirmation of 1 ts doctrine at the cost of withdrawal from the central political issues of the time. 
TABLE OF CONTENTS

CHAPTER

Page

I. PROBLEMS IN SOCIALIST POLITICAL ACTION. . . - 1 PRACTICAL PROBLEMS COMMON IN EUROPEAN SOCIALIST MOVEMENTS . . . . . . . . . . . 15

THE DISTINCTIVE CHARACTERISTICS OF THE ITALIAN SOCIALIST MOVEMENT. . . . . . . 26

II. THE PARTY'S STRUGGLE FOR ESTABLISHMENT. . . . 33

III. THE CHALLENGE OF POLITICAL ACTION . . . . . . 48

IV. PRACTICAL PROBLEMS OF THE DUAL PROGRAM IN PSI ACTION AND ORGANIZATION 1900-1920. . 68

1. The Challenge of Expandling Bourgeols Inst I tut I ons. . . . . . . . . . . . 68

2. Patriotism Versus Sociallst Principles. . 95

3. Post-war Demands for Soclalist Action . . 112

V. THE DISINTEGRATION OF THE ITALIAN SOCIALIST PARTY • . . . . . . . . . . . . 116 VI. CONCLUSION. . . . . . . . . . . . . . 132 ENDNOTES

BIBLIOGRAPHY 


\section{CHAPTER I}

\section{PROBLEYS IN SOCIALIST POLITICAL ACTION}

Sociallst polltical action provides an important example of a brave and essentially noble attempt to put a theory of social order into practice. Sociallist theory defines a fully-developed scheme for what "ought to be" in the soclal order, as opposed to what "1s," and Its polltical action is directed toward the pursult of the "ought." But this has resulted in most cases in incomplete fulfillment of Its orlginal alms because of the limitations of 1 ts theory in relation to the complexities of social conditions and practice it trled to mold.

Formulated in reaction to the excesses and inequal1ties of Industrialization in Europe during the second half of the nineteenth century, and in response to the desires and needs of the new laboring class created by Industrialization and urbanization, socialism has two basic components. It is a practical plan to change the institutions of the soclety so that economic activity comes under public authorlty and administration Instead of prlvate. It is also an all-embracling theory of history, soclety, and humanity." Sociallsm sets out an explanation of the social reality as condltions determined by historlcal necessity. It assumes, 
rationally, progressive improvement in the nature of man, glven the proper conditions. It assumes that there $1 \mathrm{~s}$. a speciflc Just and rigint order of soclety whlch can be attalned. These elements of soclalism constitute a creed, a system of bellefs whlch explalns completely the nature of reallty and defines the desired goal of human endeavor. The condition for attalning the just order of soclety Is the establishment of economic Instltutions in which the production of goods and the distribution of wealth belong to the public sphere and are regulated by public authorlty. When public control of economlc activity has been accompl lshed, and goods are dlstrlbuted according to need, all wlll have the fullest opportunity for the development of their talents and character. The world will become a reasonable, well-ordered place.

This practlcal aspect of soclallsm, the establishment of a set of economic Institutions regulated by publlc author Ity, Is not I nherently committed to any partlcular political method. It can and does operate effectlvely under both totalltarlan and democratlc polltical systems. But the change of control in economlc instltutions, from private to public authority, must be achleved in the realm of politics where declsions on the distribution of materlal wealth and on the exerclse of power in the soclety are made. The adherents of soclallsm must take action In the sphere of politlcs in order to win the necessary power (1.e. public 
support or toleration) to establish the desired set of economic Instltutions.

During the 1880s, when Marxlan soclalist ideas were winning adherents throughout Europe, most of the countrles in whlch sociallsm developed strong followings had polltical systems that were democratlc in varying degrees. 2 Democracy as a political method is not Incompatible with publle or any other form of control over economlc actlvity. Leadershlp is chosen by the vote of the majorlty of the people, but the minority retaln their rights. Democracy, then regulres two conditlons for operation: a free cholce of alternatives for the people and protection of minorlty rights with majorlty rule.

At the time of the soclalist movement's initial formation, men of the bourgeols and upper-classes were operating the Instltutlons in Britaln, France, Italy, Germany, and most of the European nations.s But the democratic polltical method has no intrinslc ldentification with the bourgeolsie or any other economic class. It requlres only the acceptance of the requirements for operation by all who seek to use 1 t.

The soclalists, seeking to implement their goal of public control of economic activity, had to formulate a policy and to organize their numbers for political action. Given the political sltuation of democratic institutions operated by men of the bourgeols class, the sociallsts had 
the cholce of operating within the existing political system and seeking to win political authority from the bourgeolsie according to the rules of the system, In order to Institute sociallst plans, or of condemning the exlsting political systems and trying to gain political control of the state by means outslde of the jurisdlction or effective control of the existing authority.

The sociallsts had two guldes by which to make this decislon on polltical strategy: Marxlan soclal ist theory and the actual political condltions in the soclety at the time. Marxist theory predicted the Inevitable disintegration of the capltallat economy upon whlch bourgeols polltical power was based, and so condemned any cooperation, collaboration, or assoclation with bourgeols polltical partles, programs, or activity. The actual polltical condltions provlded the kind of channels, if any, avallable to the soclallsts for political expression. The former guide was reasonably constant for all of the soclallst movements, but the latter varled considerably from country to country, resulting in the development of different strategles of political action among the varlous soclalist movements.

In countrles where democratic polltical systems had been established, the political means of popular election were avallable to the soclallsts, though with varying restrictions on suffrage. Most of the sociallst 
movements chose to use this method of legally recognized and orderly pursult of polltical power rather than follow the violent and extra-legal attempt to destroy exlsting political authorlty advocated by the anarchlsts.4 Popular electlons, especially if the franchlse were extended to universal suffrage, would, without question, bring the socialists to power because the working class constituted a majority of the population and, according to soclallat theory, the working class would ratlonally vote soclallst. In 1891, at the Congress of Brussels, the II Internatlonal offlclally adopted the pollcy of legitlmate pursult of politlcal power by the method of parllamentary electlons. It repudlated anarchlst and any other extra-legal means of seeking political power as "unclvilized."s

Though deciding to use the accessible legitimate method of galning polltlcal power by popular electlon, the sociallst movements metlculously upheld the doctrine of Marx. Class warfare was the Inevitable fact of history, and the sociallsts, as the leaders of the proletarlat, could in no way associate or cooperate with bourgeols polltical programs. They must stand in implacable opposition to the bourgeols ministrles and parties. Bourgeols parties and governments were Incapable of Inst ItutIng any durable change In the social order and the soclalist movement must dlfferentlate Itself entlrely from them. Consequently, soclallst polltical organlzatlons were formed to particlpate 
In the competitive struggle for the people's vote as the mandate to political power, but, at the same tlme, they were committed to bellef in class warfare and the necessity for the complete overthrow of the existing group in polltical power, the bourgeolsie.

By this decision on political strategy, the socialists found themselves in the dilemma of democratic soclalism, the dilemma which has characterlzed the political action of all West European sociallst movements. The sociallsts confronted the task of winning sufficlent power in the soclety to oust completely the bourgeols polltical leadership in order to Institute their plans for complete economic and soclal renovation, but wlthout there belng avallable any means outside the legitimate system.

On the one hand, Marxian soclallst theory precluded the basic toleration of, and compromise wlth, the various exlsting groups of the society that would be required for effective democratic action. Any hint of compromlse with the bourgeolsle was an anathema to the creed of class warfare. On the other hand, the soclalists' commltment to constitutional means of galning political power prevented them from taking recourse to any lllegal but more effectlve method, such as force, to achleve their ends. This sltuation left the sociallsts with no basis for negotlation with opposing groups to secure their ends by the means customarlly employed in the democratic system, compromise 
and collaboration, and, at the same $t$ Ime, with no recourse to means outslde of the democratic system to achleve their ends, If the flrst method should prove Ineffectlve.

Marxlan Soclallim, as a gulde to practlcal polltical action, has two great weaknesses. It limits Its pol Itical base of power to one source, the proletarlat. Other Important sources of soclal power, such as schools, organized rellglon, liberal elements of the bourgeols class, or a llberal government mlght also be susceptlble to plans for reform of soclal Institutions. Where the alm of polltical action ls to bulld support for a speclflc program, this deliberate limitation can serlously hamper a movement's effectiveness. Even more so, the Incltement of Intensely host lle feelings from other groups can damage a movement's potential for posslble success. Thls position leaves Soclallam vulnerable in another way. When Soclalism restrlcts its potentlal base of power to one chosen source, It leaves its doctrine open to critlclam if other polltical movements win support within the Sociallstg' declared realm. Secondly, because Soclallsm is an all-embracing theory, It can admit no valld devlations from $1 t$, nor recognize as legitimate any action contrary to 1 t. This is the cruclal point upon whlch Marxlan Soclalian denles the I Iberty of Independent thought or action on matters of soclal order outside of its deflned scope. It allows no rlght to a dissenting minorlty, as thls would adnlt weakness 
or fallibllity in its infallible scheme. In the tests and complexities of polltical action, Infallibllity is the most difflcult of all qualitles to clalm or malntaln.

The limitations of its theory are reflected in the Soclallsts' uncertaln political action. This condltion produces further difficulty in realizing the economic plan delineated by Soclalist theory. As the Socialist polltical organization engages in the competitive dally struggle for polltical power, factual condltions and polltical practlce produce evidence that confllcts with Sociallst theory. Two alternatlve ways of dealing with conflicting evidence are open to adherents of a systematlc theory. They can elther accept the evidence as new Information on the nature of reality and modify their bellefs accordingly, or they can rejeat the evidence, conflrming their bellef in the origlnal theory, and wlllingly step outslde part of the realm of practical polltical reality. This alternative requires sociallst adherents to adopt falth as the bridge over Inconslstencles between Soclallst theory and polltlcal conditlons. Such recourse to falth introduces a strong Irrational element Into polltical action.

Because Socialism is a fully-developed doctrlne wlth a purpose, rationale, and clalmed unlversal appllcatlon and not just a set of practlical measures deslred in political action, It has an addltional source of strength whlch more pragmatic movements do not have. It has a greater abllity 
to deny invalidating or weakening effects of attacks in practlce by calling for renewed falth in doctrine. In thls way, Socialism can ward off doubts and demands for revision In pollcy among Its adherents to a far greater degree than can most political parties. But this same characteristic, while beneficlal to the movement in malntalning the unity of Its members in falth, can have a detrimental effect in practlcal action. By slmply refusing to make any modiflcatlons in 1 ts theory or actlons pursuing 1 ts principles, the Soclallst movement can also rlsk the possiblilty of placing Itself Increasingly outside of the malnstream of political action, thus becoming less and less effectlve in Its thoughts to reallze its goals. This quandary of whether to reaffirm its principles, rejecting an advantageous, but devlant, course of action, or whether to modlfy its principles, accepting a divergent but more advantageous course of action is the persistent tension between Ideals and actlon characteristic of political movements gulded by a systematic theory. In the realm of politics with varlous agents competing for power and privileges, compromise on its declared princlples may be the only way a partlcular movement can put into effect even a part of Its speciflc program. Yet, by compromising Its Ideals, the movement rlaks losing Its unlqueness and therefore of enacting any real change at all. From its first commitment to carry class warfare and total revolution by legltimate democratic 
means, the Soclallat movement has confronted the tension between stalemate In parllamentarlan political action and betrayal of its revolutionary ideals.

Some difference between principles and practlce is stimulating to a political movement, spurring the movement to renew its efforts to fulfill its ldeal more preclsely. But if the realities of political practlce and social conditions consistently conflict with a movement's theory, the movement will undergo severe stress. Such a condltion is likely to provlde doubt and loss of falth in the movement's principles among its adherents. For example, a Soclalist party's fallure to receive the expected portion of the electoral vote may cause some of its members to reconslder the party's intransigent stand on favoring only action which promotes the expectation of imminent revolution, which wlll dislodge the bourgeolsie. In their reflections, the dlsappointed members may conclude that, despite the party's theory, the revolution is not so imminent among the masses after all and that other measures must be adopted to win the support of the workers. The Infallibility of a portion of the movement's doctrine is challenged, and differing anticlpations of the political sltuation arlse, within the movement.

Strong differences regarding the theory upon whlch a movement bases its action tend to develop further into differences among methods of political action within the 
group The more intense the differences regarding the movement's doctrine are, the less likely is the movement to carry out a common, unlfled action. Different perceptions of political realitles and different interpretations of the movement's political needs require different pollcies of action.

Thus, a Soclallst movement in which part of its members thlnk the collapse of the capltalist system is imminent, and in whlch part of its members think the Socialist revolution is some time away, finds itself with two groups urging different and conflicting policles of action. Whlle one group mlght lnclte the workers through the party press, to milltant defense of the class struggle In preparation for the revolution, another group might play down the language of class struggle as it seeks to win, in a parliament, modest reforms in hours of work and wages for the workers. Once division in the common acceptance of the doctrine of a movement has been admitted, elther overtly or implicitly, dissension on the questions of tactics and politlcal strategy necessary to ensure the movement's ends is almost sure to follow.

By the same loglc, different tactlcal approaches in polltical action requlre different types of organlzation and different bases of social power to carry them out, respectively, in the most effective way. A party engaged in an uncompromisling class war needs a mllitant, disclplined 
organlzation able to fulf 111 exactly and Immedlately orders from its leadershlp. No questioning of the authority or deviance from its commands can be allowed. It needs a cohesl ve membership dedlcated completely to the alms of the movement, without other loyaltles and distracting tles. Such a party would be strongest if restrlcted only to one class, the proletarlat, or to those who adopt without reservation the aspirations and alms of the working class.

On the contrary, a party seeking to bulld a constitutlonal majorlty in order to enact its reforms, must develop an organlzation which can secure the necessary support from the electorate as a whole. This involves galning the broadest posslble soclal base for the party and, moreover, the toleration, If not the support, of all the major groups In the soclety. All, from whatever class or temporary affinlty with Soclallst princlples, who wlll vote Soclallst, are welcomed in thls type of party.

When the dissent first ralsed in regard to a movement's orlginal doctrine has reached, through the development of differences in strategy, the stage of demanding dlfferent types of organlzation and of requlring different Klnds of soclal support for pursulng the movement's goals, the orlginal movement has become so dlvided and changed in nature that not it, but two uncompromising factions now exlst, and these naturally seek separation. The tles which once bound the groups together in the original movement have 
been subordlnated, by each factlon, to newer and more prerise values.

But movements may pass through these stages slowly, or reach one stage, and if the circumstances do not occur to preclpltate the next, they may operate at a glven stage indefinltely. The particular conditions in whlch a movement operates, internal and external resources, social and governmental Institutions, the nature of other pol It lcal groups in the country, and the character of the men who lead the party, test continually the plausiblilty of the movement's doctrine. If conditlons change, however, and the members begin to question the movement's status que in theory of action at the time, the impetus from dissension is likely to generate new divlsion.

If a doctrine for polltical action $1 \mathrm{~s}$ clalmed to be Infallible, its adherents forfeit the quality of reasonable adaptability in their princlples and actions according to changes in social and polltical condltions. And, without reasonable adaptability in theory and practlce, a pol Itlcal movement may be forced elther to schlim or to inactivity and Ineffectiveness in Its effort to reallze its goals.

It is the thesls of thls work that, given the particular Itallan economic, soclal, and hlstorical conditions, the Itallan socialist movement did not develop to the same extent the divislons leading to distinct constltutional and revolutionary parties that the other 
European Socialist movements did. The Italian Soclalist Party is caught in the dilemma of constitutionalism versus revolution. The main part of thls thesis will discuss the development of the Itallan Socialiat Party from Its organization in 1892 to Its suppression in 1925, taking up the stages of unlfication, struggle for legltimacy, confllct between constitutional lsm and revolution in polltical action, and the confirmation of its doctrine at the cost of withdrawal from the central political issues of the time. 


\section{PRACTICAL PROBLEMS COMMON IN EUROPEAN SOCIALIST MOVEMENTS}

The Soclallst movements of the European countries experlenced certain common problems in practice, and in their development, exhiblted the pattern described in the preceding section. Polltical parties were organized on the basis of Marxian Soclallst theory; conflicting evidence encountered in political action led to differences regarding theory, whlch in turn, led to differences regarding strategy and tactics in polltical action, and this condition led to demands for different forms of organization and different kinds of social support. ${ }^{\circ}$ Wlth the last stage, the various Soclalist movements split Into const Itutional and revolutionary parties, each establishing Its distinct organization and commanding a separate base of social support. That is, all European Soclallst movements except one, the Itallan, experlenced the stage of clearly defined schlsm. The Itallan Soclallst Party experlenced the break-off of separate factions for clear constitutional or revolutionary goals but its majority remains at the present time committed to const Itutional revolutionim. Nevertheless, the Itallan movement partlclpated in the general pattern of European Socialist development and thls sectlon will sketch brlefly 
that pattern.

The first major problem whlch all European Soclallst movements faced was that of unlfying the supporters of Soclal ist ldeas into a single organlzed, political party. Thls task involved the conclliation of many 1 lberal, and often contradictory, tradltions and values concerning working-class action. In every country, assorted theorles and socletles had been formed for the ald of the working class. The anarchlst Ideas of Mikhall Bakunin and Peter KropotkIn, who called for the destruction of the state or any central author 1 ty and the free assoclation of Individuals In soclety, had found particularly receptlve soll in Italy, Spaln, and France, and to a lesser degree, in other European countrles.?

Cooperative socletles and thelr predecessors, mutual ald socletles, had developed among the workers in several communitles. Thelr chlef purpose was to provide means of economic assistance and beneflts to the workers within the capltalistic system of production. Workers' partles and the early forms of trade unionism had also appeared in most countrles, for the purpose of making demands upon employers for hlgher wages, shorter hourg, and Improvements in work Ing condltions. Some impetus toward reform in workers' conditions had also been Inltlated in much of Europe, with varyling degrees of success and energy, by 1 lberal elements of the bourgeolsle, humanltarlan groups, organlzed religlon, 
or Intellectuals. The common denominator of all these groups was their deslre to Improve the llving and working conditions of the working class. The Marxlan Socialist doctrine provided the most clearly developed and most comprehensive statement of working class aims in the political and soclal sltuation of the times. In Germany, France, Italy, and most of the countrles of Europe, supporters of the working class adopted the Marxian Soclallst theory as their offlclal doctrine and formed unlfled polltical parties. It will be recalled the Brussels Congress of the II International of working class movements In 1891 voted Marxism to be the official doctrine of International Sociallsm.

Each of the Soclalist movements had to settle 1 ts own dispute on political method. The struggle between the legitimists and the anarchlsts reached very heated stages in France and Italy. Even the well-disciplined German Soclal Democratic Party had its minor bout with anarchlsts. But, the matter was offlcially settled in favor of legitimacy for all socialist parties when the II International expelled the anarchist contingent from its ranks in 1891 and upheld legitimate means as the only appropriate method for Soclallst polltlcal actlon.

But though a Soclallst party had declded to use the legltimate means of parliamentary electlons to carry out 1 ts plan for the capture of state power, It st 111 had to reckon 
with the constltutional government in offlce. At that time, most of the constitutional governments looked upon any organlzed effort to galn control of state power and to change radically the existing economic and social ingtitutions as illegitimate and subverslve. The bourgeolsie, in polltical power, had the full constltutional powers of the State at their disposal to use against the Socialists who threatened their power and privilege. In every country, the Sociallsts experlenced a hard struggle with the const Itutional government for legitimate recognition. In Germany, the Soclalists were outlawed from polltical particlpation for twelve years under Blsmarck. In France, the Soclallsts were threatened and curbed by three successive minlstrles in the 1890s. In Italy, the Soclallst Party suffered severe persecution by the government."

Established as legitlmate parties with freedom to partlclpate fully in the polltical system, the Soclallst movements were confronted with the dilemma presented by cormitment to constitutional means for the attalnment of a revolutionary end. Inevitable questions were ralsed in each of the Soclallist movements. To what extent should the Party engage in the operation of present bourgeols government In order to advance the cause of the workers? Should the Socialist Party collaborate with a bourgeois party or support the bourgeols government, if by dolng so it could win substantlal reforms for the working class? Or must it 
shun any $k$ ind of reform for the workers sponsored by a bourgeols party or government on the grounds that such reforms could only be temporary and only obscure further the real issue, the deposition of the bourgeols class and the proletarlat's assumption of power? The soclallst movements were caught in the old conflict between the desire to be effectlve in polltical action and the deslre to malntain pure ldeals.

This dilemma took on different forms in response to the specific situatlons in which the varlous Soclallst movements operated. Certain kinds of condltions were common to each situation and helped to determine a party's eventual cholce in the dilemna.

In broad outline, the Western European Soclallst movements experlenced the same serles of condltions which affected their outlook toward constltutlonalism or revolution. First, the varlous Soclallst movements encountered circumstances in political action whlch precipitated breaches in theory. The avallable channel of polltical expression provided by a relatively early and broad suffrage had already influenced the Soclalist partles' cholce of constltutional means of action. France had instituted manhood suffrage in 1848; Germany adopted the measure for Relchstag electlons in 1871, although the three-class restrictions In Prussia did l Imlt Its effectlveness; Britain enacted manhood suffrage in 1884.20 
The line between the privileged and exploited classes did not remain clear-cut. Humane and liberal elements in the bourgeolsle also began agltating for soclal reforms. Governments enacted measures of social legislation: regulations on hours of work and chlld labor were passed, the beginnings of social assistance and workman's compensation programs were establlshed, concesslons were made on wages and hours by industriallsts, and some recognition was granted to laborers' bargaining power with management. Thls situation caused some members in the Soclallst partles to doubt the urgency of class struggle descrlbed in the doctrlnes of Marx and to disapprove of the violent phraseology characterlstic of Soclallst literature. Instead, they came to readjust their expectation of proletarlan conquest of power to a longer period. To many Sociallists, class struggle appeared to lose some of its urgency. But on the contrary, other groups in the partles saw these measures as only a partlal response, tossed to the workers sporadlcally by capitalists to appease their employees most pressing demands. These Soclallsts warned agalnst the dangers of these measures to awakening the workers' resolve for revolution.

The rapid rate and extent of industrlallzation in Europe had begun to show thelr consequent effects of a general rise In prosperity by the $1890 s$ and the first decade of the twentleth century. The workers were generally better 
off in their standard of living than they had been, contrary to the Marxist prediction of Increasing mlsery for the working classes. Thls fact made the doctrine of class struggle lose some of itg relevance for those working classes, and other Issues such as natlonallsm, religion or Individual liberties caught their interest and attachment in polltics. Agaln, Sociallsts inclined toward constitutional Im saw that the general promlse of total economlc renovation would not be sufficlent to win an electoral majorlty and consldered proposals for speciflc reforms necessary to win and keep the worklng class vote. Yet, other Soclalists, belleving passionately in the Implicit revolutlonary character of the masses, held to their conviction that if the working class could only be awakened to the true sltuation, they would naturally support the Soclalist revolution.

Under the circumstances of these three condltions, the Socialist movements in all countrles developed reformist and revolutionary wings. Eduard Bernstein, in the German Soclal Demccratic Party, developed the theory of revisionism, bltterly opposed by the revolutionlsts, Rosa Luxemburg and Karl Kautsky. In France, the "possibllists" disassoclated themselves from the revolutionary "Guesdists," and at the Congresses of the II International, reform versus revolution was the central subject of heated debate." 1

These dlfferences in theory, then, led to different 
kinds of tactics adopted by the reformist and revolutionist groups in the Soclalist parties. The reformlst groups encouraged specific proposals for social legislation in the Party's campalgn programs and modiflcation of the Party's revolutionary propaganda. In France, reformist groups gradually accepted the measures of parllamentary alliance and support of the bourgeols governments, thereby galning access to direct Influence on political decisions. In Germany, the large Sociallst delegation in the Relchstag was denled the opportunity for direct influence in politics, but the reformists continued to bulld a large and wellfinanced organization for winning eventual parllamentary majorlty.12

Reformists in all countries began to lose some of their animosity toward the bourgeolsle and to engage more and more in compromise with them for short-term galns. In doing so, they dimmed the clear determination of winning control of state power for the working class. The reformists, too, saw value in malntalning associations with the growing trade unlons, compet ltors for working class support, even at the expense of conceding certaln aspects of Soclallst political authority.

On the other hand, the revolutlonarles grew Increasingly discontented with the compromise and vacillation of the reformists, parllamentary all lances, and delays in achleving any thorough $k 1$ nd of soclal reform. Gross areas 
of poverty and Inequality st 111 exlsted and most suffering was st 111 unallevlated whlle privilege and injustlce persisted. The revolutionarles sought more effectlve organlzation of the masses for the conquest of power.

At this point, all European Soclallst movements experienced the crlsis of World War I. The call to arms confronted the Sociallsts with the a conflict between two obligations: that of citizens to thelr nations, and to the cause of the International working class. Soclallst movement had to choose whether to support its nation's effort in war, thus denying one of the major principles of Soclalist doctrlne, or whether to uphold the Soclallsts' condemnation of the war as the outcome of the faltering capltalistic system, but thus perhaps contribute to its nation's defeat.13 The lssue pushed a showdown of primary alleglance and all Soclallst partles, except the Itallan voted to support their nation's war effort. In most cases, however, the action was not a sudden break with Soclallst theory but rather the logical outcome of a series of minor departures in both theory and practlce that had occurred within the Party over a period of years.

The experience of the war accentuated the difference between princlples and practlce whlch had developed earller in most Soclalist movements, but it was followed by an even more severe test. The new Communlst Internatlonal, formed and directed under the leadership of the successful 
Bolshevik revolutlonarles, called ltself the organlzation of the true revolutlonary workers partles. It alone could set the standards for the successful revolutionary action. Any other type of movement was merely one of bourgeols reform and could not properly be called revolutionary. To the end of establishing an elite organization of revolutionary working class movements, the Communist International issued a proclamation of "Twenty-one Points," that is, twenty-one conditlons whlch a working class party must fulflll in order to be admitted to the III Internatlonal and, therefore, to the ranks of the revolutlonary elite. Among these conditlons was the expulsion of all reformist members from the Party and all reformist policles from the Party's program. It required the adoption of the name "Communlst" and acceptance of the direction of the Comintern in all matters.14 The conditions amounted to the denlal of legitimate methods as the only means for the assumption of polltical power and also demanded changes in the Soclalist Party's organization and membershlp accordingly. These terms proved so contrary to the bel lefs and practlce which the reformist element in each Sociallat Party had bullt up over lts years of politlcal experience, that they were unacceptable. In nearly every Soclal ist movement, the demand for different types of organization and different kinds of soclal support made explicit the schism between reform and revolution already apparent in the parties. The 
revolutionary elements split off to form Communlst partles. while the remalning Soclalist portion adopted a more outrlght reformist policy, including particlpation in bourgeois government. The European Socialist movements, in general, abandoned the pollcy of "constltutional revolution" as the separate wings of the partles organized into constitutional or revolutionary partles. 


\section{THE DISTINCTIVE CHARACTERISTICS}

\section{OF THE ITALIAN SOCIALIST MOVEABNT}

The Itallan Soclallst Party (PSI) was the only European Soclallst movement whlch did not divide into a democratlc, gradual lst party and a communlst, revolutionary party. Instead, the Itallan Party fractured between 1919 and 1922 into three parts. The extremist faction broke off and formed the Itallan Communlst Party. The rlghtlst factlon was expelled for attempting to support the bourgeols government agalnst the Fasclst threat; it organlzed, temporarliy, a constltutlonalist party. But the trunk of the old Soclallist Party pledged to legltimate revolution remalned intact. It retalned the PSI name, tradition, and the core of its membershlp.

For what reasons should the Itallan Soclallst Party dlffer from the general pattern of European Soclalist movements? It had been founded on the same set of princlples and particlpated In the same broad cultural, polltical, and economic milleu. The differences between Itallan Soclallst development and the general pattern of European Soclalist development were chlefly differences in degree rather than $k I n d$. But the degree of dlfference was slgniflcant enough to result in distlnctive characterlstics 
for the PSI.

The speciflc condltions under whlch the Itallan Soclalist Party was founded and in which it operated differed conslderably from those of the other European Soclallst movements. Industrlalization occurred later in Italy than In Brltaln, Germany, and France, and Indeed as yet has not developed sufficlently to make the whole of Italy a modern Industrial state. Only in the 1890 s had Important advances been made In the textlle and metal industries. And the decade of the 1900 s marked the nation's blggest perlod of economlc expansion. Even then, Industrlalization in Italy did not create the huge army of urban Industrial workers that was formed in Britain and Germany. Because Italy was slow in experlencing the effects of Industriallzation and urbanlzation, the lssues of exploitation of workers and of $\mathrm{class}$ war did not become important in Italy unt Il the late 1880 s and the $1890 s$.

In the meantime, varlous other theorles and schemes for asslsting the poor and Improving the mlserable condltions of workling people had been advanced and some had developed well-establ Ished traditlons and loyaltles of their own. The anarchist movement recelved a stronger following In Italy than in the more Industrlally-advanced countries. A Workers' Party had been founded to glve organlzed expression to the workers' demands for hlgher wages, shorter hours, and arbitration boards for labor disputes. A 
Frenchman, Benolt Malon, had Introduced Ideas of social reform through a parliamentary political movement. The beglinning stages of industrialization in Italy produced diverse, ad hoc movements among the working class instead of a fairly steady development of one working-class party. Consequently, when the Itallan Soclallst Party was formed in 1892, It suffered from two handicaps in comparison with the German and the French Marxist partles. It had a late start in 1 ts struggle for political power. It had no strong unifying Marxlst tradition, its component groups already had definlte tradltions and established values of their own. From its Inception, the PSI faced the task of creating and malntaining a cohesive splrit within the organization itself. This fact, partlcularly among the leadershlp, tended to keep the party weak by preventing the development of single-minded purpose in political action. Consequently, the Italian Soclallist Party did not have the same Importance in national polltlcs as the other Soclalist parties did in their respective countries for quite some time.

The Institutional framework of the Itallan government allowed no easy access to Socialist or any working-class movement, nor did 1 t encourage the creation of a large, mass party. The franchlse in Italy was widened in 1882 , but the extension was not due to the government's magnanimity. It permitted seven percent of the population to vote instead of 
the previous two percent. Manhood suffrage was Instltuted In Italy only in 1912. This situation prevented the development of the great, working-class electoral partles of Germany and Britaln, or the relatively easy rlse of a simllar political force, as in France.

The privileged class in Italy remalned unabashedly hostlle to notions of relingulshing its privlleges for social reform. The old arlatocracy, and the owners of property and the means of productlon, retalned a sufficlent amount of bellef in thelr status as holders of privilege by right or by superlority to dismiss, without qualms, challenges to this status or pleas for the expression of social consclence. Only very slowly and to a very small extent did any appreciable concern for the welfare of the working population Infiltrate the privileged class. The hostllity of the Italian privileged class to any concessions of Its wealth or power relnforced the class-consclousness of the PSI, and the presence of no other slgniflcant reform movement in the country strengthened the Party's clalms that only complete change In economic and polltical control would allow an improvement of social conditions for the working class.

The general lack of politlcal sophlstlcatlon among the Itallan public made difflcult any kind of organlzed specific polltical action which depended on mass support. The largest portion of the Italian population had no famlliarity 
with political or governmental experlence except through heavy taxes and milltary demands. Over elghty percent of the population was 111 lterate in 1880 and the concepts of a national government, organlzed polltical action, or Influencing governmental declsions were allen to these people. They tended to choose the simplest political alternative and not to discriminate between Issues which could or could not be compromlsed. To the largest part of the supporters of the PSI, both democratlc method and radical economic innovation were desirable general goals. Their comprehension of polltical lssues did not go much beyond that general point, and, consequently, they did not demand more speclfic results.

Finally, the leadership of the Itallan Soclallst Party affected the Party's continued ambivalence between constitutlonallsm and revolution. Most of the leaders of the Party were educated bourgeolsie, drawn to the movement out of humane sympathy with the sufferings of the Itallan poor. But most of them retalned their respect for democratic Inst Itutions and const Itutional procedure, and, despite the hostllity of the privileged class, could not bring themselves to take 1 llegal action to secure their ends. The Italian leaders' sympathy for the working class in their poverty and mlsery was so great that these men would be satisfled with nothing less than a radical change in the existing economic conditions, and no other political lssue 
was more Important to them than that of the plight of the workers.

All of these conditions--late and rather $1 \mathrm{lmited}$ Industrlallzation, late unlfication of the Soclallst party without a strong Marxlst tradition, the narrow franchlse, a hostile ruling class, a general lack of political sophist Ication among the people and a lack of political expediency among the leaders--contributed to the fact that the Soclallst movement in Italy could accept the program of const ltutional revolution without much challenge. The majority of the Itallan working classes, to whom the Soclallst Party directed Its appeal, never became sufficlently involved in the national political life to see specific advantages in elther legltimate reform or total revolution, or to see any incompatibllity between the two goals. The Party's Important leaders, simllarly, never reached the polnt where a set of specific political condltions caused them to welgh the merlts of revolution or legitimate reform against each other, and to find that the advantages of one alternative outwelghed the dlsadvantages Incurred from dropping the other. The PSI leaders suspended making a cholce as to the primary value of their movement, and when the political situation did not allow the compatiblllty of the two values, the Party wlthdrew from polltical action. Sustained by the falth of 1 ts core membership, the PSI malntalned and st 111 malntains 1 ts original dual 
pollcies.

Therefore, the Itallan Soclallst movement, while following the general European pattern, has done so at a slower rate and with less Intensity. Contradictory evidence from practical experlence did present challenges to the Socialist doctrine. Dissension over theory developed withln the Party. These differences then broadened into different strategles and tactlcs in action. But these differences in theory and in strategy were debated only by the politically-active segments and leadership of the Party. The PSI's base of support, Industrial laborers and peasants from the Po Valley, never seriously questloned the valldity of the Party doctrine and continued to support the ideal of legltimate revolution. The speclflc hlstorlcal events of the First World War and the post-war chaos arrested and dlstorted the modest economlc and pol 1 tical developments of the 1900 s in Italy, developments whlch in other countrles had undermined the valldity of the legitimate revolution formula of Marxian Social ism. 
CHAPTER II

THE PARTY'S STRUGGLE FOR ESTABLISHMENT

On a hot August day in Genoa in 1892 the Itallan

Soclalist Party (PSI) was formed. Thls newly constltuted party represented the hopes of many diverse elements of the working class movement in Italy: Marxian Sociallsts, trade unionists, Mazzinl republicans, parliamentary Sociallsts, and partisans of the old Mutual Ald Societles. It also represented the recognition by the recently converted Soclalists that the previous separate attempts of these groups to protest the lot of the workers had been frustrated and were insufficlent. The party's efforts must be given new direction to achleve any changes in the soclal situatlon.

The theoretical basls of the party was strictiy Marxlst. The Congress afflrmed as fundamental truths the following principles:

All men have an equal right to the materlal and moral benefits of soclety, provlded that they contribute to the creation and maintenance of these benefits according to their abllity.

The prevalling economlc system of private ownershlp of capital is progressively dividing the society into two opposing classes: the capitalist owners who monopol lze social wealth by every means of exploltation and domlnatlon and the wage-earners, who produce this wealth but are driven further and further from enjoying the 
frults of thelr labor by the capltallst system.

This condition is intolerable and, In the name of social justice, the capltalist system of private ownership must be replaced by a system of "collective ownershlp of the natural wealth and instruments of labor." Production will then be based on the general interest and will engage all working men. This system will ultimately succeed in bringling about that perfect soclal state where all men produce according to their ability and consume according to their need.'

But the existing state, the program continued, can achleve no lasting reforms in soclety. The form of political institutions in society is determined by the form of economic relatlons and corresponds to the pattern deslred by the prevalling economlc class, whlch uses the political inst itutions to reinforce its dominance. The state, then, is the defender and tool of the bourgeols class and represents the domination of those who monopolize soclal wealth and power. It is, therefore, the natural enemy of the disinherlted laborers. It must be abol lshed and replaced by a system of administrative relations among the various segments of the population, organlzed on the basis of production, exchange, and consumption, and federated according to their interests and to their needs.

The purpose of a workers' party, the Congress affirmed, is to provide consclous leadership to the milltant proletariat in its struggle for polltical power. It must serve as the falthful interpreter of the proletarlat's goals. Constantly, the Party must seek to strengthen the proletariat in its battle againgt bourgeois domination and to malntain its independence from any other leadership 
group. The movement of the proletarlat was geen as unlque in the present soclety; all other contenders for power, even though they Impose reforms, stem from the corrupt capitallst system and must be overcome.

With these statements, the Congress agreed unanimously on the necessity for the working class to rise in opposition to the existing political and economic system and to overthrow it completely. The delegates were not in complete agreement, however, on the form this struggle was to take. Two opposing conceptlons of the workers' struggle were presented in a controversy which was not new to the workers' movement. The anarchists maintalned that the oppression of the present state would drive the workers, sharing their same sufferings and the same hopes, into spontaneous revolution againgt the existing system in order to secure a condlition of free and harmonlous assoclation among individuals. Poverty alone determined the wlll and the capacity of the masses to revolt.

The legalitarlan soclalists, led by the intel lectuals of the Milan Soclallst League, objected vehemently to the anarchist position. They rejected the anarchist methods of violent and sporadic uprisings as immature and insufficient In the soclal struggle. Moreover, such methods had falled miserably to arouse the masses. They asserted that the social revolution could not be miraculously achleved in a particular moment, but must be the outcome of innumerable 
preparations. The revolution would be complete only when the new order commanded the vital organs and strata of soclety and possessed the full powers necessary to acm In lster the functions of soclety.

The Marxlan Soclallsts denounced the use of vlolence In the soclal struggle. Sociallsm, In essence, was a set of values to be translated into action. They asserted that vlolence was not a force, but only obscured soclal consclence. Thus, the social revolution would be stronger where there was less violence.

On the basis of the above conditions, the soclallsts termed the anarchists and thelr program Incompatible with the best interests of the working class movement. They Insisted that since the primary task of a working class party was to organize all laborers into a single, unifled movement that would work clearly and efflclently toward the realization of thelr goal, such a party must eliminate any dissident elements that would frustrate its action. The socialists called upon the Congress to expel both the anarchists and the cooperatlvist element, whlch was seen as interested only in seeking easler terms of co-existence with the capltallst system for the workers.

By a majorlty vote, the Congress passed the motion expelling the anarchlote and trade-unlonists. This vote decislvely determined the character of the new party for, in accepting the resolution of the legalitarian soclalists, the 
Congress had afflrmed the necesslty for the abolition of the capitallst system and the bourgeols state, and had rejected the use of violence to attain its goal.

The baslc lssues settled, the Congress, under the direction of the Mllan Soclallst League, hastened to constitute Itself a party for the purposes of leading and organlzing the working class in lts struggle for soclal power. It set up an Executive Commlttee and a form of organlzation for local sections. Declsions on pollcy and principles would be made at perlodlc Congresses of the party members. The final authorlty in the new party would reside with the majority of the Congress, 1.e. With the majority of party membership as represented by delegates from the local sectlons. The Soclallist party accepted democratic princlples within Its organization, but denled it to social process. It would not grant representation or minority rights to capitalists who stood outside the circle of those worklng for the genulne welfare of the whole soclety. In elaborating its strategy for pursuing radlcal social change, the PSI flrst wanted to win a wide base of soclal support. The party needed to attract supporters to its program in order to organlze the proletariat. Prohlbited from recourse to violence, the Socialists saw the necessity of using all the processes and position of social Influence accessible to it, such as elections, public offlce, and the press. Through these it would volce its 
protest against the bourgeois order and present its alternative program. Designating itself as the party of the working class, the PSI directed Its appeal malniy toward the workers, the largest, most oppressed class of soclety. In its political activity to win popular support, the Socialist Party planned to deal with the immediate problems of the workers, focusing on their demands for shorter hours, higher wages, unemployment compensation, and the like.

The Party reconclled thls activity in legitimate channels with its revolutionary program by considering securing improvements in the workers' Immedlate conditlons to be a necessary preparation for the seizure of total power. Moreover, the Sociallsts differentlated their measures from similar reforms proposed by liberal partles or truly popular governments in that the Socialist measures would ultimately lead to abolition of prlvate ownership, while the non-sociallist reforms would leave the present economic base of soclety intact, thus falling to resolve the underlyling social problem.

The Party's first task in the political struggle was to gain acceptance and freedom of action within the bourgeols society to carry out its program of seizing social power. To gain a flrm establishment, the Party needed to Increase its base of power and as a constitutional party. the principal means open to 1 t were acquisitlon of electoral support and polltical influence in Parliament. This 
presented a problem to the Soclalists in that the steps which would lead to greater success in these methods of increasing its power, cooperation, and compromise with other representatives of soclal power might also weaken the strength of the Party's revolutlonary character. The Party resolved the issue by adopting a policy according to which It would partlcipate in electoral campalgns, but would malntain a rigld practlce of non-collaboration with any bourgeois party. To consolidate its forces in Parliament, the Party agreed that the Soclalist deputies should form a delegation responsible to the Party. $=$ These measures represented the PSI's first compromlse between its two goals in a practlcal situation.

The historical events lllustrate, however, that the revolutlonary goal of the Party hindered its constitutional development and that the Party's consitutional values hindered the development of its revolutionary character. In its bid for social establishment, the Party's revolutlonary alms caused it to suffer stern repression at the hands of the state. These clashes presented serlous threats to its legal exlstence, a primary requirement for a constitutional party. Three historical instances serve to llustrate this point: the uprising of the sicllian peasants and sulphur miners in 1894, the rebell lous demonstrations of the peasants and quarry workers in Lunlgiana in the same year, and the bread rlots in Milan, in 
1898.

These demonstrations were essentlally outbursts of soclal unrest among the workers and peasants against particularly severe economic hardships. The Sociallsts, in each case, had not planned the outburst. But when it occurred, they had moved into the disturbance and attempted to direct it toward Soclalist goals. The state, however, Interpreted the incldents as Soclallst-inclted threats to the civil authority and took extreme measures against the Soclalists in defense of the constitutional order. 4 Military troops were sent to put down the demonstrations; Sociallst leaders were arrested and Imprlsoned and, in 1894, the Sociallst Party was ruled illegal. Its adherents were forbidden to assemble and its publ lcations were suppressed.

Thus threatened, the party sought to defend its exlstence. Powerless to act agalnst the State's superior force, the party took recourse to the only means of defense open to it, constitutional protest and appeal for popular support. It denounced the vlolent actions of the government as odlous in civil soclety and explained its own position as unassoclated with violent means. Rather, the conception of "revolutionary evolution" meant that the soclallst pollcy would gradually galn strength and support from the members of the soclety until it became the dominant force, when it would then declare the soclallzation of property by 
constitutional means.: Indeed, the Socialist leaders explicitiy stated thelr rejection of violent action as a means for obtaining social power in the following statement: If the use of vlolent means, whlch horrlfy the human consclence more for their stupldity than for their ferocity, is intended by revolution, we are not revolutionary, for such means are inadequate, hateful, and premature. And they are incompatible with, and contradictory to, our ideals."

The Party Congress at Florence in 1895 gave formal expression to the Soclalist renunclation of violence. It passed a revolution stating that: "no member of the PSI should accept the judgment of arms to resolve any question with any one for any reason on any toplc." $>$ The Sociallst leaders asserted the constltutionality of thelr own action in contrast to the atrocities it said were performed by the State. By drawing the distinction between social transformation and violent action in the use of the word "revolution", the Soclallsts could clalm full legltimacy for their actions within the present order, thus diminishing the cause for their persecution by the state, and st 111 adhere to thelr Marxist tradition of total social revolution, on whlch they based the party's appeal to the workers.

The effect of this pollcy, whlle conslstent with the literal principles of its program, was to de-emphasize the revolutlonary character of the party by pushing the transformation off into the future. The constitutional nature of the party, on the other hand, was emphasized. The party won a substantlal increase in popular support but 
largely for reasons beyond Its Marxist appeal. The de-emphasis on revolution in its program of social change, comblned with a genulne wave of sympathy felt for the party as the victim of State persecution, attracted non-proletarlan elements to the party, notably intellectuals, students, and humanltarlans indlgnant over working-class conditions. The general high regard for Soclalism at this time among the notable Italian intellectuals is shown by a survey taken in 1895. Out of a selected group of Intellectuals Intervlewed, 151 out of 194 endorsed Soclalist beliefs. And, of the 151 respondents approving of Soclalist doctrine, 110 did so without qualifications. The sample consisted of 105 writers, 63 sclentists, and 26 artists. Later, In 1896, when the PSI felt sufflclently stable and wealthy to undertake the publication of a newspaper, many of the best intellectual figures of Italy pledged to contribute to thls organ, Avant 1. 10

The Ilberals, too, turned agalnst the government in reaction agalnst such represslve measures and threw their support to the Socialists in their concern for clvil liberties. The general elections also reflected the new sympathy for the Soclallst cause. In the natlonal electlons of 1895, the Soclalists won seven additlonal seats over their previous five in the Chamber of Deputles. In fact, three of the Slcllian Soclalists, who were sentenced to 
prlson for their role in the local uprislngs, were among the deputies elected. The party received its strongest

electoral support in the industrial provinces of Lombardy and Pledmont, with siclly rankling next.12 The number of Sociallst deputies continued to increase in election after election.

This influx of supporters proved a mixed blessing to the party. They represented, on the one hand, an increased base of social support, but on the other, they introduced new demands and Ideas divergent from the party's program and doctrine. The Influx posed a fundamental conflict to the PSI. For success in constitutional action, it needed to secure the widest possible electoral base, yet for success in carrying out its revolutionary aims, It needed maximum control over membership and organlzation. The pressure of continued persecution from the state subordinated the resolution of this issue of discipline within the party, only to raise others.

The Socialist deputles, seekling to increase their strength in confronting the government in Parllament, agreed to an informal alliance with two parties of the Left, the Radicals and the Republicans. Nelther of these partles accepted Marxist teachings, but they both joined the Soclallsts in rigld opposition to the government. The government's repressive tactlcs in handling recent ep isodes of soclal unrest had allenated them stlll further. 
Together, the three delegatlons composed the "Extreme Left" in Parliament anci strove to oppose any government measure. 2 That this strategy increased the influence the Soclallsts were able to exert in Parllament is demonstrated by an incident involving constitutional proceedings. The Cabinet, Impatlent with the Incessant obstruction of the Extreme Left, attempted to force measures to limit debate upon the Chamber by royal decree. The Extreme Left ralsed vehement protest and the 1 iberals and moderates in the Chamber, incensed by such unconstltutional procedure, jolned them in opposition to the government. The king was forced to dissolve Parllament and to call for new elections in May 1900.13

The Soclallsts, elated by the success of thls tactlc, agreed to extend their cooperation with the Radicals and the Republicans to the ensulng electlon campalgn. The three parties agreed not to flle competitive candidates in order to maximize the strength of each party. This strategy also brought fruitful results for the Sociallsts; the party recelved an increase of twelve seats over its previous twenty in the Chamber. The Extreme Left together held sixty-seven seats.

These successes did not receive unanimous approval within the party, however. The majority of the proletarlan membershlp regarded any collaboratlon with non-Marxlst, 1.e., bourgeols, parties as a betrayal of the workers' 
cause. They feared that through such collaboration the party would become commltted to pollcies which called for less than total exproprlation of capltal and abolition of the state. If so, the party would lose its revolutionary character and soclal problems would remain unsolved. Party leaders defended the pollcy, citing the necessity of attracting allies in pursulng a sucessful political strategy. $1=$

Essentially, the lssue under dispute was how the party could partlclpate most effectively in the bourgeols political order to make gains for its cause and still malntaln the distinct character of its principles. The Incldent ralsed the problem of confllcting goals and brought Into overt disagreement differences of bellef within the Party regarding the fundamental direction of its pollcy. But under the more urgent pressures from the state, the party postponed open discussion of the lssue within its organlzation and therefore postponed also the search for a satisfactory resolution of $i t$.

W1th the undenlable success of the 1900 electlons, the PSI had won its first major battle. It had establlshed itself flrmly as a recognized representative of a segnent of the population and as a partlclpant in polltlcal affalrs, recelving support from all reglons of the country. ${ }^{2}$ It had proved Itself a force whlch could not be suppressed, el ther In soclal activities or In Parllament. It had acquired the 
necessary elements of legitimacy, sufficlent popular support as shown by the electoral returns, approval and support by intellectuals and men of publlc affalrs, a recognized measure of power in Parllament and substantlal freedom of action within the present order, Its leaders were released from prlson, and Its publlations were permltted to resume operation. The PSI had become a duly established const Itutlonal party and had achleved substantlal advances towards its constitutional alms.

How did these advances relate to the revolutionary character of the party and In what ways had the party developed toward reaching its goal of revolution? In fact, each of these constitutional advances had tended to divert the party away from the simple pattern of revolution and to involve Its energies in more and more complex adaptations to social life in the present order. As these problems arose, the Immedlate threat to the legal exlstence of the party. whlch was accorded primary importance, deferred consideration of them in terms of finding thelr best resolution to advance the goal of galning total soclal power. Tenslons rose notlceably within the party over its locus of authority, rules of disclpline, resolution of differences, and control over membershlp, all of whlch were vitally Important In the effectlve execution of a revolutionary program. Fallure to confront these lssues on their first appearance, and to establish preclse, undlsputed patterns or rules for 
each of them, weakened the party's capacity to cope with political conditions on 1 ts own terms and to utllize even antagonistic social forces for lts own ends.

These issues in the development of the party as an organization in seeking social control had been subordinated to the requirements of constitutional establishment in the first stage of the party's history. This pattern undeniably influenced the character of the PSI and the manner with whlch it would deal with later challenges in the polltical struggle for social power. Conflicting values demanded the subordination of one to the other in the party's struggle for establishment. The Itallan Socialists placed the higher value on existence as a constitutional party; consequently, It developed those aspects which would strengthen 1 in in constitutional activity and neglected those qualitles whlch would prepare it for carrying out a program to overthrow the present order. 
CHAPTER II I

\section{THE CHALLENGE OF POLITICAL ACTION}

The election of 1900 marked the beginning of a new period in the development of the Itallan Soclallst Party (PSI) and Its relation to society. The electorate had demonstrated a new support for the PSI by electing thlrtythree Soclallsts to the Chamber of Deputles. This number represented an Increase of thirteen over the prevlous delegation and Included many of the Soclallst who had been Imprlsoned following the Mllan rlots.' The king, InterpretIng the electoral returns as a popular reglstration of dlsapproval agalnst the reactlonary policles of the preceding government, and as Increased sympathy for I lberal and Sociallst positions, chose a constitutionalist 1 iberal, Gluseppe Zanardel11, to form the new Cabinet. Zanardell1's government undertook the task of re-establishlng parliamentary procedure in the Chamber and of conflrming the constitutional rlghts of free speech, free assembly, and free press to all persons or groups acting within the law. Thls change in governmental pollcy meant that the soclalist Party could pursue its pollcles without threat of arbitrary persecution from the government. Its leaders could legltimately propagate the Party's program and !ts Journals 
could freely be published.

The government also showed a new toleration for the Soclallst program and a noticeable concern for social problems In general. Glovannl Giollttl, the new Minlster of Interlor, declared that the causes of the great differences between the rich and the poor lay in the process of Industrlalization and accompanylng conditions. The squalor and poverty of the working class had been accentuated both by the press of population increase and the concentration of population in the citles. 2 Census flgures show that the population of the country increased durling the perlod of 1862-1901 by nearly one-third. 3

$\begin{array}{ll}\text { Year } & \text { Population } \\ 1862 & 25,000,000 \\ 1872 & 26,801,154 \\ 1882 & 28,459,628 \\ 1901 & 32,475,253\end{array}$

The percentage of the total population living in communities of 2,999 Inhabltants or fewer decreased by approximately twenty percent, while, correspondingly, the percentage of the population living in cities of 2,000 to 100,000 Increased. In fact, the number of citles falling within the 20,000 to 100,000 range doubled. These conditions made temporary crlses even more acute among the working class.4

On the other hand, there was a relative Increase of prosperity in the soclety in response to its economic expansion. More savings were deposited in the banks. More consumer goods anit services were avallable. Transportation 
tion and communications faclilties were extended and made accessible to a larger portion of the population. Greater economic advantages were now avallable wlthin the soclety and the workers and peasants became Increasingly aware of them. They also realized that pursult of economic advantage was linked with polltical action. The lncreased number of poor in Italian society seemed to be the chief cause of imbalance in its condltion.5 Glolitti defended the Chambers of Labor as representatlves of the workers' Interests before the Chamber of Deputles and advocated thelr legal recognition.6

The increased number of intellectuals who lent their sympathles and interest to the party 11 lustrated another slgniflcant change in soclal attitudes favorable to the PSI. The group now showing sympathy for the Sociallsts Included many who had prevlously been hostlle to the party's efforts and beliefs.? Avantl! reached a wider audience. Robert Michels describes public opinion toward the PSI in 1900 as changed in large part and observes that "the Soclallsts are no longer regarded as obscure consplrators or dangerous wrongdoers." macy for its operation and a new prestlge within the soc lety.

The party had gained Increased support for two reasons: its stand agalnst the abrogation of constitutional rights by the Pelloux and earller governments in the late 
1890s, and its position as the only political party devoted. to alleviating the problems of poverty among the lower classes. Agaln, the party had recelved and welcomed the support of people who were not necessarlly comitted to the complete overthrow of exlsting institutions. The important point of this change in attitude toward the Soclalists by the government, among the Intellectuals, and among the general public, was that the PSI now had new opportunities to develop Its constitutional character. Slgnificant element in the society showed encouraging receptivity to Soclallst princlples.

In part, the causes for these changed soclal freedoms of political activity after 1900 , coupled with the new social conditlons, precipltated a tremendous growth in the formation of Peasant Leagues and Chambers of Labor." In 1900, there were thirteen Chambers of Labor In the country; In 1902, there were elghty Chambers with a total of 350,000 members. Peasant Leagues, whlch were almost non-exlstent in the prevlous decade, numbered 1,293 In 1902. The Leagues clalmed a total of more than 250,000 members.10

Strikes and other labor agltatlons broke out in protest against inadequate wages and workers' benefits. This economic activity spurred polltical organization, too, and the membershlp of the Soclallst Party increased slzeably.

These facts Indlcated a new interest in economic and 
political questions on the part of marrled workers and peasants. The awareness of want, perhaps more than want Itself, had been intenslfied among the working classes. This signifled that the Soclallst Party had new opportunlties, also, to recruit supporters for its program of class war and revolution.

The changes in soclal attitudes and condltions implled a new role for the Socialist Party within Italian society. It now had the capabllity of acting politically. And Indeed, the situation required action if the party were to increase Its power and advance its aims as a social organlzation.

But these changed soclal condltions presented new problems to the PSI in Its program of political action. To determine the best means of advancing its ends of achleving soclalist control of soclety by constltutional means, the party needed to evaluate 1 ts new situation in terms of 1 ts ultimate goal. The party as a whole reafflrmed the general polnts of its doctrine: bellef in the natural evolution of soclety toward the soclal order of collective management and ownership of property, conviction of the necesslty of struggle between the social classes to bring this about, and conviction of the certainty of the proletarlat's success in this struggle. But the new situation in which the party found itself, a sltuation whlch demanded responses to particular problems, made it necessary to state more 
specific principles as bases for action. The attempt to do so made clear the fundamental Incompatibllity of the party's two principal goals, achleving total soclal revolution and following constitutional procedure. The greater the degree of specificlty used in defining methods to strengthen the constitutional character of the party, the greater were the $1 \mathrm{Im}$ tations placed upon the revolutionary nature of the party and vice versa. Mulling over this problem offlcially at the Party Congress at Rome In 1900, the delegates differed strongly over which set of princlples the party organlzation should pursue, over which goal was primary.

Two groups, one emphaslzing constltutional procedure and one emphaslzing $\mid \mathrm{mm} l$ nent revolution, defined different polltical requlrements for Soclalist success. These dlfferences Implled fundamental disagreements in the Ir conceptlons of the nature of social change and of the PSI's role in soclety. The group devoted primarlly to constitutional means, led by intellectuals of the Milanese Socialist League, Fllippo Turati, Leonlda Bissolati, Claudio Treves, Ivanoe Bonoml, and others, reconsidered Its conception of society and agreed that society would not necessarily be forced to a catastrophlc end as the inevitable result of class warfare. It observed that in the complex process of political action the bourgeolsie could not be ellminated elther by a general strike or by a parliamentary majority. Rather, the party must work to build a Soclalist consclence 
and a Sociallst culture among the masses to enable them to take over the direction of soclety and, further, to sustain the new order. The moderates considered the preparation of the proletarlat for 1 ts task of directing soclety to be the crux of the workers' struggle. Only when the absolute majority of the people had accepted the soclallst values of the equal worth of individuals--with regard to production, according to abil 1 ty, and with regard to consumption, according to need--and when this majorlty had reached a sufficlent stage of Intellectual, physical, moral, and social development to enact the soclallst order and to uphold its laws, could the final aim of Soclallim be realized.

To the moderates, who accepted the principle of Marxian materiallam that economic conditions determined the moral and cultural qualities of people, development of the moral and cultural qualitles of the proletarlat presupposed a change In the Industrial and economlc structure of society. By this reasoning, the constitutionalists belleved that it was possible to improve the lot of the workers before the rule of the proletarlat was establlshed. The PSI must concentrate 1 ts efforts flrst on achleving practical reforms for the workers in their dally $l i f e$ and work. For, as the proletariat developed its culture and capacities, it would Inevitably bring about the Sociallst order. In planning a Soclallst program on the basis of these 
princlples, moderates belleved that the party must consider which measures should be taken to promote the economic, soclal, and cultural development of the proletarlat as well as which measures would increase the party's political power. The party's test for accepting any method in the Immedlate political situation must be whether or not it would advance the development of the proletarlat. Conversely, any pollcy whlch tended to hlnder thls development must be rejected.

The moderates concluded that the conditlons of soclety requlred two practlcal pollcles for soclallst success. First, the PSI must "consolldate Its llbertles", I.e., strengthen the position of legitimacy it had won in the const Itutional order. The moderates urged steps whlch would increase the party's effectiveness in a constitutional order: 1) to ensure guarantees of the rlghts of citizens before the courts and the pollce; 2) to reinforce the constltutional rights of freedom of speech, assembly, and the press which were necessary to the party's political operation; and, 3) to achleve unlversal suffrage and proportional representation. The party must secure the complete neutrality of the state in regard to all disputes between capltal and labor. And it must try to secure unlversal suffrage and proportlonal representation so that the full force of the proletarlat could participate in the political struggle. This position implied that the 
Soclallst Party must disclpline Itself to the full practice of constitutional rules in relation to the rest of soclety.

The moderates set the "conquest of polltical power" as the second task for the PSI. They defined this conquest as the extension of the party's electoral base, seeing the polls as the only means to power open to a constitutional party. To extend its base of electoral support, the Soclallst Party had to demonstrate to the workers that it represented thelr hopes and asplrations and that it strove to redress thelr grievances.

In order to marshal its polltlcal power most effectIvely to carry out such tanglble improvements, the PSI faced another problem of strategy. It must sustain the support of the members and followers which it had already galned. This objective required the party to take cognlzance of the demands of 1 ts supporters and to strive consclously to reinforce their falth in Soclalist bellefs and programs. The party must give substance to the demands of 1 ts current supporters as well as seek to enlarge the base of lts support.

The moderates proposed measures which would benef it the working class directly as guldes for party action. They urged such legislation as regulations on labor for women and chlldren, compensation for injured or disabled workers, and improvements on laws governing the conditions of work. The moderates' proposals also Included measures whlch were 
deslgned to strengthen the soclal position of organized labor and to extend its area of social influence. The development of a nationwide arbitration system for labor dlsputes, nationallzation of transportation and industries In the natural resources sector where cooperatives were not feasible, and the creation of a Ministry of Labor were to be among these steps.

The moderates advocated the pursult of another type of policy for the party program, measures which would improve the general culture and welfare of the workers. These Included compulsory secular education without charge to all chlldren through the fifth elementary grade, and development of public sanitation systems and hyglene regulations.

Taken as a whole, these proposals for political. economlc, and cultural reforms formed a logical coherent program of action in regard to workers' problems for a constltutional party. No one's rlghts would be harmed by violent action. The proletarlat would develop its capacities in the legal manner which it must sustain in the Socialist order. The needs of the present would be met. The moderates called it the "Minimum Program" or "that which we cannot do without" In the development of the socialist order of society.12

The second major group within the PSI, composed largely of veterans of the old workers' movements prlor to the PSI and young Idealists fresh from their study of Marx, 
emphaslzed the urgency of social revolution. It interpreted the party's increased capabllity for action in its new circumstances as confirmation of the Inevitable success of the proletariat in winning control of society. It considered the persecutions of the PSI in the preceding period as evidence for the necessity of the class struggle and recelved the signs of response to Sociallst propaganda endeavors from the workers as encouragement for the party's efforts. Thls group was more convinced than ever of the validity of the Soclalist aims as set down in 1892, and of the certainty of the party's success in pursuing this program. The only way to win lasting reforms for the workers in soclety was for the workers to assume power. Under Sociallst guldance, the workers must take control of management and production. The capltalist system and the bourgeols state must be completely replaced. Only then can the new Soclallst order of soclety to designed and executed In detall. Consequently, the extremists defined the primary task of the Soclallst Party in this perlod to be concentration on achleving complete control of soclety at the earliest possible time.

To bring about this change, the extremists contended that the Socialists only needed to arouse the workers to act in their own interests, which were embodied in the Sociallat Program. The Socialist Party must present the accurate prospectus of social events to the workers and Instruct them 
in the method of realizing their asplrations--equitable shares of the goods and privileges of soclety whlch would allow them to develop their fullest capacities as human beings. The party must above all present its program to the workers as unlque and distinct from all other parties. It must concentrate all its efforts on achieving its central goal, control of society. It must avoid the danger of developing an attachment to the bourgeols order by any political activity. Therefore, the party must never collaborate with bourgeols parties on any pollcy, as this practice could only compromise Socialist aims. It must be wary of securing reforms for the workers, lest they become too content with their present conditions and lose the sense of urgency of achleving the social revolution necessitated by the class struggle. It must be careful not to become too Involved in projects which would distract the energies of the party from concentrating on its central goal.

Most of all, the extremlst group feared the appearance of factions in the party, differing over principles and political strategy. Such a breach would foolishly weaken the party's strength against its enemies.

Given these considerations, the extremists recommended strlct adherence to the original Sociallst principles defined in 1892 as the basls for PSI policy in its new opportunity for political action. Non-collaboration with bourgeols parties or the bourgeols government and continued 
recrultment of workers to give force to the Soclalist program must be pursued to achleve the revolution. This group urged the party to reaffirm these princlples as its "MaxImum Program" and to base 1 ts strategy on them as the 15 hlghest hopes. 12

A third group within the PSI expressed its conception of the workers' struggle and proposed a program for the party at the same Rome Congress In 1900. Led by Arturo Labrlola, a follower of Georges Sorel, this group advocated the syndlcallst program for the Soclalist Party. It held that the workers would organlze a general strike as the quickest and slmplest way to eliminate the bourgeolsle. If all the workers lald down their tools at once, they would totally incapacitate society and enervate the bourgeols power system. The workers could then assume power and take up the direction of soclety. Thls position commanded only a small body of supporters at the Party Congress and did not offer serlous competition to the Minimalist and Maximalist factions. Signiflcantly, however, It directed its pleas for support only to working men and to radlcals.13

By their statements, the two major groups within Itallan Soclallism posed the fundamental confllct withln the party. One group emphasized constltutional procedure in party activity; the other stressed the necessity for imminent revolution. Both were recognized goals of the party. Yet, the differences in the speciflc programs 
outlined to fulflll these two goals revealed baslc dlfferences in the assumptions underlying the acceptance of the two goals.

The Minimallgt and the Maximallst groups based thelr respective programs on different conceptions of soclety. The Minimalists vlewed soclety as a complex order of human Institutlons where all of men's varlous qualltles and conditlons--moral, intellectual, spiritual, economic, polltical, and soclal--interacted with and Influenced each other. The worth of all individuals is equal and no man has the rlght to do vlolence agalnst another. Change in the order of society, therefore, must be gradual.

In contrast, the Maximallsts regarded society as a simple assoclation of men in whlch one particular form of soclal organlzation was imposed upon the whole by the class whlch held the most power, 1.e., which controlled the wealth and privileges of soclety. Change In the soclal order could only be brought about by superlor power. If the other members of soclety felt this prevalling order to be unjust or wrong, they only needed to organlze in a sufflclently strong body to force the ruling class out of their positions of power. Once this fact was accomplished, the oppressed members could abolish the old order and establish a new order according to thelr ldeals of soclal justice.

The two groups also differed in thelr conception of 
the nature of the PSI as a social organization. The Minimalists regarded the true character of the party to be what it actually is at a glven perlod. Using this guide, the party leaders should assess its strengths and 1 ts weaknesses and plan pollcy to maximize its existing strong points. In this way, the party could consolldate lts gains and minimize its losses in the process of achieving the Sociallst Program.

The Maximallsts, however, consldered the true character of the party to be the ideal of what it should be. On this basis, party pollcy should always be deslgned to fulfill the ldeal. Any faults in the party's organization and action should be corrected, any weaknesses should be ellminated; but the party must act always on the basis of Its ideal form. Anything less would make the party lose its unlqueness, and fall to solve in any enduring manner the problem to which it addressed itself.

Disagreement on these three assumptions--the nature of society, of social change, and of the PSI as a soclal organization--led to widely differing conceptlons of the role of the party in the present society. The logical conclusions of the reasoning of the Minimallsts were Incompatible with those of the Maximalists and vice versa. The Minimalist group concelved the role of the party to be that of providing leadership toward a gradual transformation of the materlal and moral conditions of the soclety to the 
polnt where the majorlty of the people would voluntarlly accept the principles and enact the provisions of the Socialist program. Performance of this role required above all the practice of constitutionalism, the acceptance of certaln restrictions on the party's own soclal action in order not to violate the legal rights of others, and conversely, ensuring its own freedom of action from violation by other parties or social institutions.

The Maximalist group, on the contrary, considered the role of the Sociallst Party to be solely one of leadership of the proletarlan class in 1 ts struggle for selzure of complete control of the society. Thls role required the party's rejection of any responslbility to the existing society and the concentration of all its efforts on the one goal of securling workers' control of soclety as soon as possible.

The programs for the PSI in response to its new conditions for potentlal action presented by the two groups demonstrated clearly that the two goals to which the party subscribed in theory were incompatible. The Minimalists' program grew out of the constitutionalist principle that control of soclety cannot legitlmately rest in the hands of one particular group or class, but must be based upon the consent and approval of the majority of the population. The Maximallsts, however, recognlzed only one class, the proletariat, as legitimately eligible for the direction of 
society and denled the premise that this proletarlat owed responsibility to any other class or order of social control. Elther group could not accept the principles of the other and still hope to realize its own objectives. Pressured by the fear of schlsm, the Socialist Congress attempted to resolve the differences between the Minimallsts and the Maximalists by adopting both programs, the first as the means to the second. The Soclalist leaders justifled this decision by carefully worked-out reasoning. They declared the Minimum Program to be the guide to the immedlate problems of economics and polltics which the party faced. In this way, it would serve as the means to the party's greater end, the revolutlonary transformation of soclety into a system of workers' control, defined by the Maximum Program.: The Congress bolstered this somewhat artiflcial reasoning by re-asserting the general Socialist goals in traditional Marxist language. Both the Maximallst and the Minimalist groups professed their alleglance to the ultimate aim of collective ownershlp and management of the society's production and their solld unity in assisting the workers in the class struggle. The Soclal ist Party had offlcially adopted a new program to serve as its basis for political action.

Despite its blending of these two goals by sdopting both the Minimum and the Maximum programs, the PSI failed to solve equally sat lsfactorlily the practlcal problems 
involved. In practice, the two programs were still loglcally in conflict on two areas essentlal to the operation of the party. These were the relation of the party to the existing structure of soclety and the composition and Internal organization of the party. In the first area, the problem remalned unresolved of whether the party should be constitutional in relation to the democratic state and to other parties and Institutions within the society. Thls problem would arise in declsions regarding the party's tactical strategy, whether or not 1 t should seek expansion of Its power only by means of the legally established channels of electlons, parliamentary alliances, and participation in the "bourgeols" government. It would be thereby involved in the kind of relationships that other elements of the working class movement, such as trade unlons and peasant leagues would have to the PSI. Resolution of this question determine the party's policy in regard to situations of social unregt or popular agitations-strlkes, uprlsings, and local demonstrations of dlscontent, both in ldeological content and In terms of tactics.

The second area in which the Minimum and Maximum Programs would conflict in practice was over the party's composition and Internal organlzation. Dependent upon the position taken on the means of expanding its power, the party, if constitutional, must seek to increase its membershlp and electoral support by every means possible, 
admittIng all persons who wished to Identify with the PSI for any reason. If the party rejected any responsibility to the existing system, but sought to carry out 1 ts program to replace It completely, it must seek to maintaln control over Its membership, admitting only those who were wholly dedicated to Socialist principles and programs, refusing admittance to all others. Such members might introduce doubt and dissension into the party ranks. Simllarly. problems are Inherent in the combination of the Maximalist and Minimalist goals regarding the internal organization and structure of the party. A constltutional party would require final authority within the party to be held by the membership. In a party emphasizing revolution, final authorlty must lie uncondltionally with the leaders. Discipline within the party would also present occasions for controversy. In a Maximalist program, no minority position contrary to that of the leadership could be tolerated. The leaders must be free to give or change orders at wlll as they judge the sltuation and be able to rely on these orders being executed by the membership. Under the Minimal ist conception, expression of minority opinion was a constltutional right.

The role of doctrine was construed differently under each program. The Minimallsts would loglcally use it to adjust party bellefs to changing factual conditions in the social situation. The Maximalists, however, saw Its 
Importance as lying in interpreting changes in factual conditions in the light of Soclalist principles, thereby reinforcing the convictions and falth of Party members in these princlples.

Conflict on these lssues would create further conflict on the matter of tactical maneuverability for the party. Fallure of the Congress' motion to resolve the question of whether the party should act in accordance with constitutional principles or in accordance to the principle of expediting the workers' revolution would hamper the development of a party organization adequate to carry out elther goal successfully. The ability of its organization to meet the challenges of dally polltical problems and to use them to further Its ultimate objectlve would alone determine the effectiveness of the party. The actlons of the PSI under its dual program in regard to the practical problems posed by its new social situation demonstrated the tendency for each goal to limit the development of the other, thus leading to ineffectlveness of the party in establlshing and reachlng any objectlve. 
CHAPTER IV

PRACTICAL PROBLEMS OE THE DUAL PROGRAM

IN PSI ACTION AND ORGANIZATION: 1900-1920

Part I. The Challenge of Expanding

Bourgeois Institutions

Able to engage In polltlcal actlvity without threat of suppression, the PSI entered fully into the constructive pursult of 1 ts program of collectlve ownershlp and management of production under the Dual Program in 1900. It continued its operation under this program for the next twenty years of its history. During this perlod, however, the PSI encountered speciflc political events and conditions which served to test the program's viability.

The Party confronted three major historical problems during this period. Through the years.1900-1911, a liberalreformist, democratic government was in power and oversaw the gradual development of the nation's economy. Second, it faced the lssue of "patriotism" versus Socialist principles ralsed by the war crises of 1912 and 1914, and agaln in a dlfferent form, by the Bolshevlk Revolution in 1917. And third, the economic and soclal crisls following the end of World War I presented the party, then at the peak of its numerical strength, with specific demands for 
political action. In each sltuation, the party proved unable to define a workable policy of action under the Dual Program. Each challenge made the two groups within the party recognize more distinctly the inadequacy of the Dual Program to serve as a gulde in principle or in pollcy for realizing their particular objectives. It became increasingly apparent that the two goals of following const Itutional procedure and promoting urgent total social revolution requlred different pollcles in relation to the existing government, polltical parties, and soclal institutions, and that they requlred different forms of organlzation within the party Itself. Consequently, when the expliclt opportunity for the PSI to take pol Itlcal action was presented in the social crisis following World War $I$, the party was unable to act. It could not muster its powers to carry out a single goal and thus proved its ineffectlveness as a social organization. The schisms of 1921 and 1922 within the party were, therefore, not surprising.

The purpose of this chapter is to lllustrate the progressive deterioration of cohesion within the PSI as the party's two goals proved incompatible in practice. One group sought to sustain the legltimacy whlch the party had won over the previous elght years and to extend it further. The Itallan economy showed no slgns of Imminent collapse in the first decade of the twentleth century. Rather, It showed slgns of a marked expanslon, as did its accompanying 
bourgeols institutions. The latter, indeed, showed tendencies toward social reform and revitalization. To the Minimalists, this meant that the PSI would have to counter these tendencies and establish 1 ts own scheme of social transformation with the majority of the population. The PSI might even have to appeal to certain middle class groups for support on non-revolutionary grounds. Once it received this support, the party could hope to use it to in!tiate reforms and to transform the society to the polnt where the majority would accept the Sociallst order.

The other strong group in the party recognized the signs of economic discontent and inclinations toward political action among the Industrlal workers and the peasants as verification of the party's original theses of class warfare and the necessity for overthrowing completely existing bourgeols institutions. The Maximalists contended that the PSI must, above all, represent the true interests of the working class and the ideal of the soclallst society in all political lssues and questions of the day. It must clearly demonstrate its intention of revolution. In this way the workers would recognize their natural alleglance to the PSI and organize under its direction to replace the bourgeols institutions. The Maximalists sought to appeal only to the workers; and they felt that, to gain the workers' full confldence, the PSI must prove beyond doubt that it had no taint by association with "unjust" 
bourgeois institutions. Moreover, the PSI must not betray the workers who had already accepted the party as the defender of thelr needs and the leader of the social revolution.

The social composition of the party at this time presented an Interesting pattern. In 1903, Robert Michels conducted a survey of Soclallst Party membership, sending questlonnaires to all sections of the party. Elght hundred and three sections responded and reported a total of 33,686 members for the PSI as of December 31, 1903. The breakdown of this membership, according to profession, is given in the following table: ${ }^{1}$

$\begin{array}{lc}\text { Qccupation } & \begin{array}{c}\text { Percentage of } \\ \text { Membership }\end{array} \\ \text { Industrlal workers } & 42.3 \% \\ \text { Artisans (skilled workers) } & 14.9 \\ \text { Agr lcultural l aborers } & 15.0 \\ \text { Share tenants } & 6.1 \\ \text { White-collar workers } & 3.3 \\ \text { Small busl nessmen } & 4.9 \\ \text { Professionals } & 2.7 \\ \text { Students } & 1.1 \\ \text { Others } & 9.7\end{array}$

By far the largest portion, nearly three-fourths of the total membership of the party, consisted of rural and urban manual laborers. Thls is a very signiflcant figure in the party's history. The petit bourgeolsie accounted for approximately fourteen percent of the total membership and the intellectuals only four percent. The smallness of this latter group is noteworthy, consldering that the leadership of the party was drawn heavily from this group of educated 
persons. Of the thirty-three Socialist deputles in Parl lament in 1903, twenty-eight were university graduates. Three of the remaining deputies were engaged in lower mlddle class occupatlons and only two were wageearners. Only one of the party leaders, Costantino Lazzarl, was a wage-earner and he was an accounting clerk.

The gross differences in number and in character between the manual workers and the educated group presented recurring problems to the party. Though the leadership of the party was shared among the small group of less than four percent of the party's total membership, the final authority for party action rested with the large segment of manual workers. This segment, the least experlenced in political action, was to prove the most inflexible to change. Secondly, though the PSI's legitimacy in society rested chlefly with the professional and middle-class elements, the proportion of these groups to the manual workers in the party membershlp was small.

Having accepted two different types of soclal support and having committed 1 tself to two conflicting models of soclal change, the PSI confronted the polltical problems of the time, declaring lts unity in devotion to the cause of the working class. The first problem whlch the Sociallst Party met upon its emergence into free political action in 1900 was a liberal, democratlc government concerned with introducing social reforms of its own. What relation the 
PSI should bear to the state In Its effort to enact this program of soclal transformation preoccupled the party as the question demanding the major focus of 1 ts attention and energies through the years 1900-1911. Three historical phenomena occurred within thls period, each of whlch forced the lssue to the party's Immedlate attention and required some $k$ ind of decision.

The favorable climate for soclal reform during the decade was the flrst of these phenomena. The intellectuals wrote about the need for soclal reform. Parliament sponsored an inquiry into poverty, investigating the living conditions of the peasants, and an Intensive report was presented to the Chamber. The Catholic Church stated its position on the lssues of poverty and soclal welfare, and liberals in Parliament were interested in introducing reforms. In fact, over the decade, Parliament enacted a series of soclal welfare laws. Largely initiated by Giolitt, the list of welfare measures included the following: 1) a serles of publlc health programs; 2) regulations regarding the prevention of accidents in factorles; 3) 1 imitations on working hours for women and children; 4) a national insurance and pension scheme; 5) relief for poverty in the South; 6) manhood suffrage; and 7) subsidies for cooperatives. a Clearly, the Soclalists by no means had a monopoly on ldeas or proposals for soclal change. 
In presenting 1 ts concepts of reform and in seeking to win supporters for them, the PSI had to formulate some $k$ ind of pollcy toward the speclfic attempts for reform being made within the soclety. According to the Minimum-Maximum Program, the PSI's task was to Improve the working and living condltions of the working class in order to enable it to bring about the social revolution. Social reforms Initiated by bourgeols parties or the bourgeols state could mean elther of two things: an opportunlty to further the improvement of the workers' condltlons, or a hindrance to the workers' realization of the injustice of the existing regime, thus showing the necessity of overthrowing it.

Within the party, the MInimal lst and Maximalist groups reacted differently to the bourgeols tendencles toward reforms. The Minimalists, committed to the constltutional procedure of social change, consldered the receptivity to soclal reform on the part of the government, the parties, the Intellectuals, and the population generally as an advantage to the party's cause. They saw an opportunity to Increase electoral support by continuing and extending the informal alliance establlshed in the prevlous decade with the "closely-related" Radlcal and Republ lcan partles. At the PSI Congress at Imola in 1902, the MInlmalists proposed that the party ally with "closely-related" parties in local elections. 4

The possiblitty of using the PSI's Increased prestlge 
and authority to speak for the working classes to better advantage in Parliament seemed important to the Minimalists. At Regglo Enilla in 1893, the PSI Congress had resolved that the Soclallst deputies in Parllament should form a delegation to increase the effectiveness of their efforts, but stated that this delegation should be held directly responsible to the Party Executive. The Executive Committee, in turn, was elected and glven Its general direction by the Party Congresses.s Thls practice had been continued under the Dual Program. The Minimallsts complained that the Soclallst Delegation was unable to act declslvely on speciflc dally lssues as they arose in Parl lament. Opportunities were lost before the Party Executive could be consulted or a Party Congress called. To gain more flexibllity for Soclalist action In Parliament, the Minimalists recommended that the Social ist Parliamentary Delegation be removed from the control of the Party's Executive Committee.

Since the Minlmalists comprised a majority of the PSI Parliamentary Delegation, ${ }^{\circ}$ this proposal would, in effect, have freed the Minimalist deputies to carry out their own conception of the Soclallst program in Parliament. The Party Executive would be relegated to a secondary position without substantlve control over soclallst activity in this Important area. The Party Congress defeated thls measure at Imola in 1902,7 but the Minimalists continued to seek other 
means of increasing Sociallst power by constltutional methods.

The question of gaining more support for measures advantageous to the Soclalists by cooperating with nonSoclalist partles gave rise to the more serious issue of whether the government should be supported when it initiated measures of social reform. Through the years 1903-1913, Giolitti introduced such a series of legislative proposals and, in each case, the question arose concerning what position the PSI should take in regard to governmentsponsored reform.

The issue presented itself at the first Party Congress followlng the adoption of the Dual Program, the Congress of Imola in 1902. The Minimalists considered any proposal which brought genuine improvement to the workers an advantage to the Sociallst cause of raising the general standard of living among the workers, and one which the party should support. The Minimallst position declared that there was no possibility of Judging the question whether or not the PSI should support the government except on the basis of each particular case and set of circumstances. The question continued as a source of dispute throughout the perlod.

The Minimalists felt the party's progress toward increasing its number of supporters and areas of power through electoral alliance wlth other parties and parliamen- 
tary collaboration and support of the government when approprlate for the Soclallst cause was hampered by one characteristic--its revolutionary-Marxist tradition. The mlitant language and radical tone taken by the Maximalist deputies In Parliament made the atmosphere "unpleasant" and, the Minimalists charged, frightened the government from making possible concessions to Socialist demands. ${ }^{\text {a The }}$ Maximalists refused to discuss day-to-day political problems in anything but terms of class war and revolutionary language.

Secondly, the Minimalists criticized the propaganda disseminated by the Maximalists as typical of the outdated PSI assertions of the preceding decade and as presenting to the workers an oversimplified and vislonary conception of the Soclallsts' struggle and the nature of the future soclety. They feared that the traditional conception would lead the workers to belleve that the task of establishing a Socialist order would be easy and could be carried out quickly. The workers would then fall to see the difficulty in the prospective process of social change and, consequent$1 y$, would not understand the delays and the frequent changes of method involved in bringing about the legitimate transformation of society into the Sociallst order successfully.

The next weakness which the Minimallsts saw in the PSI's action under the Dual Program was the lack of a 
realistlc sense of responsibllity to the soclety. The Minimalists voiced this criticism first at Imola. But the workers' General Strlke of 1904 provoked the strongest reaction by the Minimalists agalnst any type of violent or direct action undertaken In behalf of the workers' movement. Action outside the limits of 1 aw and concern for the soclety's welfare would not only allenate public sympathy from the Sociallat Party and hinder the party's chances for increasing its strength by legitimate means, but it also would go beyond the limits of essential Socialist principles. The pith of the Soclalist program was legitimate soclal change for the general welfare. Considering the effects of the PSI's traditional characteristics of militancy and lack of sense of responsibility to the exlsting order upon its present action and situation, the Minimalist group recommended that the party largely drop its violent Marxist language in favor of terms less offensive to other groups. It urged also that the party present its goals in more realistic terms, in order that the workers and other members of the population might understand more clearly both the problems and galns Involved.

Last, the Minimalists reiterated their conviction that only by following a well-developed policy and by acting responsibly within the society could the PSI achieve the necessary conditions of approval and acceptance to carry out 
Its alms of establishing collective ownershlp of property and management of production. All three recomnendations for change requested essentlally that the PSI temper 1 ts revolutionary manner and adopt a more moderate tone in politics.

The Maximallsts judged the inclinations and acts of the bourgeols governments and parties toward social reform to be a danger to the Soclalist Party's program and expansion. They regarded any reforms inst ituted by the bourgeols government or achleved in collaboration with bourgeols parties to be temporary appeasements granted to the workers' grlevances and Intended to divert the workers from thelr natural course of revolution agalnst the exlsting order. The Maximalists held that the PSI's pollcy in regard to any non-Sociallst proposal for reform or scheme for political action should be total abstinence from any $k$ ind of cooperation or support. They objected vigorously to the practice of informal electoral alliances with the bourgeois parties which the PSI had taken up in 1900, and declared that it should be dropped. Although the Minimalists succeeded in passing a measure whlch offlclally sanctioned such alliances in local elections at the Congress of Imola In 1902, it was over the objections of the Maximalists. Later in 1902, an incldent occurred in the local elections of Cremona which particularly incensed the Maximalists. The offlclal PSI newspaper, under the 
editorship of Leonida Bissolatl, a member of the moderate group, supported the candidate of the Radical Party in fulflliment of such an electoral agreement over a local Socialist running for the same office. The Maximalists consldered such an act to be one of flagrant indiscipline and an unconscionable violation of Sociallst princlple.

Similarly, the Maximalists felt the PSI should refrain completely from any cooperation with the bourgeols parties In Parliament. Such cooperation could only taint the Socialist objectives with partial reforms. The PSI must not appear to the workers to be wavering in its ideal of total social revolution. The Maximallsts had agitated for discontinuling the informal parllamentary all lance which the PSI had established in 1895. They feared that parliamentary cooperation would lead to a weakenling of the party's resolve to carry out a complete social revolution. The Maximalists insisted on this point of non-cooperation with bourgeols parties for the PSI again and again throughout thls period and the Maximalist deputles continued their own policy of refusing to do so in Parliament. 10

The Maximalist position on the question of whether the PSI should ever support the government followed from Its stand on electoral and parllamentary all lances with bourgeois parties. It was unconditionally negative. Varlous Incldents occurred whlch led the Maximallsts to clash with the Minlmalists over PSI practice in this regard. 
At the Congress of Imola in 1902. Antonio Labriola stated the position of the syndicalists, the extreme faction within the Maximallst group. He declared that the PSI should stand in uncompromising opposition to the government even on its proposals of simple reforms such as--regulation of working hours and enforcement of sanitary conditions. He reasoned that these measures only distracted the workers' attention from the necessity for revolution and lulled them to false contentment with their lot.

In 1 ate 1902 , certain Sociallst deputies agreed to partlclpate In government commlttees in Parliament, including one whlch drafted proposals for a military project.12 The Maximal ists were outraged at this action taken under the Socialist Party name. They thought that PSI action in Parliament should be restrlcted to presenting proposals whlch were distinctly Soclallst in nature.

The issue of PSI support for the government stirred continual controversy within the party over the period from 1900 to 1911. The Party Congresses of Imola, Bologna, and Rome debated the issue at length and with much strong feeling on both sides. When the Minimalists assumed the leadership of the party in 1908, they directed its action in Parllament until 1911 according to their convictlons, but not without opposition from the Maximalist element.

The Importance of the Maximalists' criticism of the character and operation of the PSI was that the practices 
which it considered detrimental to the development of the party were the same practices which the Minimalists regarded as most essential. The one characteristlc of the PSI which the Maximallsts found harmful to its mission as the vanguard of the proletarlat was its tendency towards graduallam and conciliation with the bourgeois parties and institutions. The PSI, according to the Maximalist conception, had to demonstrate to the laboring classes its complete rejection of, and disassociation from, the bourgeols order of society. The division within the party leadership over these issues became more pronounced. The leaders supporting the Minimalist position were intel lectuals, journalists, lawyers, and unlverslty graduates. They were, on the whole, men associated with the moderate journal Critlca Sociale, and committed to ideas of legitimate soclal change. Their number Included Filippo Turati, editor of Critica Soclale, Leonida Bissolatl, Camillo Prampolinl, Nicola Badalonl, Claudio Treves, Ivanoe Bonomi, and Antonlo Grazlodel. Almost the whole of the Soclalist Parllamentary Delegation followed the Minimal ist position, as well as the heads of the workers' cooperatives.12

The Maximalist leaders, in contrast, were men bred on workers' socialism: Costantino Lazzari, Romeo Soldi, E. C. Longobardi, and Arturo Labriola. A cluster of Sociallst deputies associated with the syndicalist ideas of Enrico Ferri defended the Maximallst position, as did the leaders 
of the workers' socleties and trade unions. 3 The two differing perceptions of the workers' struggle, which these men had subordinated in 1892 to the need for strength gained from common endeavor, began to re-emerge in the problems of Judgment and Initiative of dally political action.

The second historical phenomenon whlch the PSI had to conslder during the years 1900-1911 was change in the composition of the party's membership. This was due, in part, to the new pollcles which the party exercised and, in part, to changes in the political outlook of various segments of the population following new developments in their economic and social conditions. As the Socialist party began to lose its stigma and to gain respect from the State, the intellectuals and, among the population, generally, the extent of 1 ts attentive audience enlarged. Outside the class of manual laborers, not only professors and university students, but also white-collar workers and State employees found Social ism attractive and responded to the appeal of Its new Minimum Program. Railway employees, telephone and telegraph operators, and elementary school teachers, for example, were all employed by the state. Poorly pald, they had little or no reserve against illness or loss of their jobs. The reforms outlined in the Soclalist Minimum Program represented the closest solution to their problems offered in contemporary politics. A large 
number of white-collar workers, many of them state employees, Jolned the PSI for these reasons, while not committing themselves to the end of total soclal revolution or the destruction of capltalist bourgeols institutions.14 The Minimalists regarded thls addltion to the PSI's number as an Increase in the party's electoral and parliamentary strength and as an advancement in the party's acceptance by the soc lety.

At the same $t$ lme the PSI recelved thls influx of new members, it received an additional increase in membersh ip from another segment of the population. Revolution-orlented workers from newly formed Chambers of Labor and from syndicallst-influenced labor organizations joined the PSI as the proper organlzation through whlch to manlfest what they saw as thelr political interests and to conduct their political activities. Agricultural workers from the recently organlzed Peasant Leagues also joined the PSI. These groups made their attachment to the PSI as the party of the proletarlat in the class war. To them, it seemed the instrument by whlch the future social order of collective ownership and management of production would be brought about.1 $1=$

The Maximalists considered this addition to the party's ranks evidence of the fact that the workers were reallzing the necessity for class warfare and were looking to the PSI for leadership in the social revolution. A 
marked increase in the number of labor disturbances and agitations in the early years of the decade appeared further proof to the Maximalists that the time for the mass workers' uprising was very near.

The Maximalists vigorously opposed the entry of white-collar workers Into the party ranks. They considered the whlte-collar workers allen to the real revolutlonary class, the manual laborers. The white-collar workers, it was felt, did not accept the necessity for overthrowing exlsting instltutions and therefore only constituted a hindrance to the PSI. The admission of these white-collar workers to the party would undermine its revolutlonary strength.

A party whlch supports 1 tself on the shoulders of the white-collar workers employed by the State, or that goes begging protection from them could never be a serlous danger to the existence of the State. In fact, the State has but one function for the white-collar workers, that of the purse, of granting increases in wages for them. ${ }^{26}$

At the Congress of Bologna in 1904, the issue of membership composition was debated at length. The Maximalists, led by Labriola's more extreme group, expressed their definitive opinion that "the party must bar all those adherents who came from the middle classes, for example, the petty rural proprletors, the school masters, and white collar workers." $1>$

Conversely, the Minimallst group regarded the entrance of the new revolutionary element into the party as a 
hindrance to 1 ts conception of the PSI's development. They called this increase of the revolutionary element injurious to the party but declared it impossible for the Socialist Party, traditionally the refuge of the discontented, to prevent the inflitration of "maniacs who are not able to adapt" into Its ranks.

The Minimalists, seeking the widest possible base of social support, could refuse admlttance to party membership to no one. The Minimallsts were afrald that the revolutionary character and acts of these new workers' groups would allenate support already won for the party from the non-proletarlan elements of the soclety and frighten away possible recruits from these groups.

An incldent whlch lllustrates the offense done to the base of support of one wling of the PSI by actions undertaken for the success of the other wing is the General Strike of 1904. Labor disturbances had broken out again in siclly in the fall of 1904. Discontent spread among the workers. The Syndicalists, led by Labriola, inltiated the general strike, organized through the Chambers of Labor. The strike was carried out as representing the entire labor movement, though without the approval of the Minimalist Soclalists. The strike was successful, inasmuch as workers in all industries throughout the nation left their jobs. It brought no conclusive changes in the organization of production, however, and after a few days of expectant 
walting for the total collapse of the economy, the strlkers, dislllusioned and hungry, returned to work.

The real effects of the strike appeared after the workers were back on their Jobs. Prime Minlster Giolitti, had allowed the strike to play itself out without the interference of the state. Then he called a general election. The general public was disturbed by the display of workers' radicallsm demonstrated by the strike and was annoyed at the Inconvenience caused by the stoppage of public transportation and communication facllities-sanltatlon, llght, and drinklng water servlces, the dally press, and the production of bread. Consequently, in the ensuing election, the Socialist Party lost parliamentary strength. The number of its Parllamentary Delegation dropped from thirty-three to twenty-seven. 19 The Minimalists were shocked and Indignant over the occurrence of the general strlke. Thls radical action by the workers had offended the groups in the society to which the Minimalists looked for support and which granted the legltimacy necessary to their conception of the PSI's success. Indeed, the event prompted the Minimalists to reconsider the traditional Soclalist doctrine in the light of present social conditions. At the next congress of the party, the Congress of Rome In 1906, a group on the rlght within the Minimalist faction presented a proposal to the assembled delegates which denled the Marxist theory of class 
warfare and the inevitable disintegration of the capltalist institutions. It proposed, instead, reform within existing Instltutions as the program for soclal change for the PSI. In presenting the resolution, this group of Minimalists admitted they were renouncing the privllege of representing the Marxist tradition.

This open renunclation of Marxist theory by the Minimalists in turn offended the revolutionary current in the party. They blamed the fallure of the general strike on the Minlmalists' gradual $1 \mathrm{sm}$ and reforml sm wh $1 \mathrm{ch}$ sapped the revolutionary enthusiasm of the proletariat. At the Rome Congress, the manual workers, representing the majorlty of the party, did not understand the practlce and implications of the reformism of the Minimallsts and were frightened by its seeming exaggerations and inconsistencies with the proletarlan cause. Consequently, the Congress did not adopt the Minimalist resolution.21 But neither did it pass a program of open class war, continued strikes and agltations by the workers, as advocated by the syndicalists. Public sympathy was agalnst radical action, in contrast to the wldespread support in the earlier uprisings in sicily, Lunigiana, and Milan. This was demonstrated by the Sociallst losses in the elections immediately following the General Strike of 1904. Parliamentarlsm seemed to have penetrated the public mentality to the degree that any other means seemed Imprudent or Immature. $2 a$ 
The General Strlke of 1904 had an unanticlpated effect In reference to the potential source of social power to which the PSI directed Its appeal. The Cathollc leadership had been growing increasingly more tolerant of the secular state and less doctrinaire regarding its ban on political particlpation by 1 ts adherents. The episode of the General Strike had aroused Church leaders to the threat posed to their own institutions by a radical workers' movement and to a sense of their own responsibillty in the exlsting soclety. 23 The stimulus to the not yet developed political sensibllitles of the Cathol ic leadershlp represented a potentlal competitive force among Catholic workers and peasants with which the PSI had not reckoned. The rise of the Popolari, the Cathol lc mass party, after the war of 1914-1918 was to demonstrate the force of this competition.

As a result of the experience provided by the strlke, the two groups within the PSI realized more clearly the antagonisms between their basic positions. Still, neither group could convince the majority of the party membership, the manual laborers, of the rightness of 1 ts position alone. And neither group would deny its mission of leadership of the working class or its devotion to thls cause. Consequently, the PSI Congress of 1906 conflrmed once more the equivocal program of the necessity for class struggle and the practlce of legal means in carrying out the Soclallst alms of collectivization for the workers. 24 
The last major historlcal phenomenon whlch the PSI confronted in carrying out its program for workers' revolution was the product of the gradual development of the nation's economy which had occurred during the decade. ThIs had also allowed cultural and social improvements for the population. Moreover, the nation experlenced, during this decade, a perlod of domestlc and external peace, which allowed the social changes to evolve relatively free from interruption or severe crisis.

Many of the workers' needs which had been demanded so militantly in 1901-1905 had been fulfilled by a combination of welfare legislation and a general increase in economic prosperity. More jobs were avallable; more consumer goods were in the shops at lower prices; wage increases had been granted; some of the more pressing soclal reforms had been enacted. At this time, the national federation of trade unlons elected to Its Executive Committee men of Minimalist Socialist political convictions. This slgnified that the General Confederation of Labor (CGL) confirmed a pollcy of legal reform in pursuing the interests of the workers. The Syndicalists and their proposals for simple revolutionary action by the workers' movement had, to a considerable degree, been discredited in the eyes of the general population by the general strike.

These changes in the economy had produced changed attitucies in the population. As their needs were more 
satisfled. Italians became less discontented and less susceptible to proposals for revolution. The attachment of the trade unions to the Socialist position represented a very slgnificant shift in terms of the Maximalist program. The CGL represented approximately 800,000 workers. This was a large portion of the speciflc population to which the Maximalists appealed for support. This shift to what was essentially the Minimalist position presented a serious liability to the possibility of the Maximalists ever winning unquallfied control of the party, or more important, the society.

The PSI's offlcial policy of "Integralism" was at this time highly superficial as a statement of the party's values and as a directive to its actions. Nelther the Minimalist nor the Maximalist wing admitted the validity of limitations imposed upon Its own values by the requisites of the other's values. The party's acceptance of the integral ist formula depended, therefore, largely upon the personality of the faction's leader, Enrlco Ferrl. Ferrl, a dynamic, magnetic personality, had a remarkable capacity for making difflcult problems appear to be very simple. Supremely confldent in his own powers, he inspired confldence among other people in his personal ability to handle complex situations and issues. The situation arose that the integralists' dynamic, if erratic, leader suddenly left his offlces in the Party Executive in 1908.2s This occurrence undermined the 
integrallsts' policy thoroughly in the party and left the position of leadership open. Since the acceptance of social reform by legitimate means had generally increased with the society and among a signiflcant portion of the workers' movement also, the Minimallsts won the control of the PSI's Executive Committee quite easily in 1908. The Minimallsts' base of support had widened considerably in the two years since 1906 and it continued to increase through the next three years.

Al though the Minimalists declared, when they assumed control of the leadership, that revolutionary syndical ism In the workers' movement was dead, they could not, by their own principles of legitimate procedure, expel the remnant of the revolutionary group from the party. Nor was revolutionary fervor dissipated outside the Socialist Party and the CGL. In certain regions of the country, particularly Parma, Ferrara, and Milan, fresh revolutionary uprislngs among peasants and industrlal workers occurred in 1906, 1907, and 1908. The Incidents spurred political and economic organization among the workers and they adopted the doctrine of class warfare and total revolution in their newly-formed Chambers of Labor and Peasants' Leagues.

An interesting turn of events took place among these new revolutionary groups in 1908. Frustrated after a series of strikes and agitations had ended in fallure, the workers became sympathetic to the appeals of the new prophets of 
revolutionary nationalism whlch began to be heard in Italian soclety. Gabrlele D'Annunzlo represented the splrit of this movement. The ease with whlch revolutionary workers shifted their loyalties is signiflcant in the light of a later crisis in the party, in 1914.

At the end of the period 1900-1911, the PSI had developed to the point where the two wings within it realized the discrepancles between their positions in the workers' movement. Each succeeded in winning a separate base of soclal support for Its distinct princlples and character. The quandary of the party, however, consisted in the fact that the majority of the party members, the manual workers who were largely silent in party discussions and debates, remalned unwilling to relinguish fully the tradition of revolution or to forego the possible achlevements of reform within the existing social structure. They provided the most substantial base of support for the workers' movement and neither of the two rival groups of leaders were wllling to cut themselves off from it. Nor was either group willing to renounce its claim to leadership of the universal workers' movement. To do so would have reduced the validity of the principles each group advocated. For each group, this supposition provided the basis for its reasonling and princlples.

At the end of the party's first decade under the Minimum-Maximum Program, the incompatible duality between 
programs of legltimate action and total social revolution remained the goals accepted and tolerated by the majority of the PSI members. This group was largely inactive in political affalrs and did not face the practical contradictlons involved in attempting to carry the Dual Program into action. Social conditions in Italy were such that the Dual Program remalned plausible to this segment of the population. It was accepted by the workers insofar as the MInimalists afflrmed total soclal revolution to be the net result of their efforts. The Minimallst leadershlp, dedicated flrst to legltimate goals, appeared superficial to the gross largest element of the party's membership, and, to be permanent, had yet to win thls membershlp to a position where it shared its convictions fully. 


\section{Part II. Patriotism versus Sociallst Principles}

The Socialist Party had been gradually growing in coheslon under three years of relatively unchallenged Minimalist leadershlp when it confronted the jarring event of national war. The Giolittlan government declared war on Turkey September 9, 1911, ostensibly to protect Italian investments in Libya which were being threatened by increased Turkish activity in the province. The war was brlef, though costly, and in 1912 Italy won her show of strength and forced Turkey to cede Libya and Cyrenalca.zo

The Libyan War posed a difficult issue to the PSI in 1911. The party could not avold this major event in Italian polltics; it had to take a position in regard to it. According to the tradltional Soclalist princlple, war was the inevitable result of the capitalist system. Capltallst nations engage in war, driven by their internal necessity for imperialist concentration and international competition In order to perpetuate themselves. They are driven to war also by the need to disperse domestic political conflicts, which will ultimately prove their downfall. War is a sign of deterloration of the capitalist nation and the Socialists must stay steadfast in their principles of unqualifled opposition to the bourgeois ingtitutions in order to lead 
the working class in its inevitable triumph.

Yet, in 1911, the PSI had reached a new point of strength within the legltimate society. The Socialist Parliamentary Delegation numbered forty deputies and promlsed to become substantlally higher with the prospect of passage of the government-initiated manhood suffrage blll in the next year. In fact, the government had recently recognized the increased influence and strength of the Socialist Party in Parllament by offering a cabinet post to Bissolati, a member of the PSI Parliamentary Delegation. Substantial improvements and reforms had been secured in working class conditions through legitimate means. To oppose the government's policy of war in confirmation of traditional Socialist princlples would mean the rejection of all the party ties to the legitimate society--the gains it had made and lialsons it had establ lshed. On the other hand, to support the bourgeols government's war pollcy would mean effective renunciation of the basic principles of the Socialist Party.

The party was immobilized in its first reaction to the declaration of war, but then split deeply under the pressure of the crisis. The legalitarians on the right end of the Minimalist continuum, Bonomi, Bissolati, and their followers urged that the PSI support the government in Its war enterprise. These men had, In the preceding three years, undertaken a campaign through Avant l! to educate the masses 
to parliamentary methods and legitimate goals. They had consistently cooperated with the IIberal governments of the past decade and they still felt this policy to be productive and essential for the workers' cause. They refused to consider the government's declaration of war sufficient cause for disrupting their pattern of parliamentary cooperation in the name of what they considered "outworn revolutionary princlples."z>

The nucleus of revolutionarles in the Maxlmalist wing reacted vigorously to the situation and confirmed without hesltation the traditional Marxian Socialist principles. The event represented to them the unquestionable confirmation of their revolutionary thesis. The manual workers in the party, led by Lazzari and representing the largest segment of the party membership, also confirmed immediately their original Sociallst convictions and declared that the PSI had no choice but to denounce the government's engagement in war. Hostile demonstrations against the government punctuated their assertions. ${ }^{20}$

The most interesting reaction to the crisls within the PSI was that of the Turati-Treves group, the remaining section of the Minimalists. Although the members of this group saw merit in the practice of legitimate methods in behalf of the working class, they still accepted the basic Marxist principles regarding the fate of bourgeois institutions. Secondly, they were bound by their own principles of 
legitimate action in regard to the authority within the party. The legitimate authority rested with the majority of the party members, and Turat $i$ and Treves would not consider tranggressing the majorlty's will. The unity of the working class movement, under a single set of leaders, was by far its most potent polltical characteristic and they would not disrupt it.

At the Party Congress of 1912, the Maximalists clearly received the majority of the membership's support for their proposal of unconditional opposition to the government, then engaged in war with Turkey, and ungualified reaffirmation of Socialist principles. Dominating the Congress, the Maximalists succeeded in winning another victory. The new nucleus on the left in the Maximalist wing. incensed by the overtures of the legalitarian Bissolat 1 to the bourgeols government, demanded that he and his small group of followers be expelled from the PSI. A previously little known figure in the Maximalist ranks made the speech requesting the expulsion of these veteran party leaders. He was Benito Mussolini, a fiery Romagnole who preached a new klnd of Soclallsm, one that was more violent and more emotional than usual even for the Maximalists. His demands and doctrines for PSI action were even more extreme than those of the Maximalist proponents of Syndicalism who initiated the general strike.

Though not wholly in agreement with the language and 
assertions made by the Maximal ists concerning Soclalist opposition to the national war, the Turati-Treves Minimalist group submitted to the Maximalist proposal as the official PSI program voted by the majorlty of the party representatives. The Congress concluded with the Maximalists assuming control of the PSI Directorate. Lazzarl took over the chairmanship and Mussolini, the fast-rising new flgure among party leaders, became editor of Avantl!.

The change in the PSI's character and activities under the direction of the Maximalists became quite apparent. Avantl!, previously engaged in soberly educating the masses of workers to parliamentary methods and legitimate goals, 30 now incited the workers, through its pages, to take up the most radical and direct kind of action in order to bring about the social revolution. ${ }^{1}$ Sporadic outbursts of violence and strikes, instigated by Soclallsts, occurred in several areas, particularly among the share-tenant peasants In Emilla-Romagna. ${ }^{3 z}$ The party had assumed a dlstinctly radical and belligerant manner in its relations with existing parties and institutions.

As this new radical character of the PSI developed more and more fully in the party's activities and statements, the Turat l-Treves contingent became increasingly critical of the Maximallst leadership. They denounced this new form of Socialist behavior as "fatuous revolutionary Ideal Ism" and charged Mussolinl with throwing over the 
philosophy of historical materialism as the core of Socialist principle. They criticlzed Mussolini's propaganda as claiming impossible achlevements for the strength of will and Ideas of a few select men. ${ }^{9}$ The Minimalists' dissent from the Maximalist direction of the PSI grew, and the party's temporary external cohesion induced by the crisis of 1912 decreased.

The outbreak of European war in 1914 brought a still more severe crisis to the PSI. The war of 1911-1912 had been a relatively limited, national enterprise, but it had still compelled the Socialists to reconsider profoundly their ideals and the program of their party. In the summer of 1914, the major countrles of Europe were at war, and Italy faced the possibllity of becoming involved. As the Socialist Party had recently affirmed, the support of any war policy stood in direct contradiction to its ideals. Yet, the question posed by Italy's possible involvement in an European or more extensive war was whether the existence and strength of the Italian Socialist Party was separate from. and independent of, the Italian nation. The direct challenge of international war to the principles and essential character of the Socialist movement demanded the formulation of a speciflc pollcy by the PSI in terms of its goals in regard to the war.

Officlally, the PSI reacted to the situation with remarkable cohesion. Having just defined its position with 
respect to war in true Marxist terms in 1912, the PSI, as a whole. staunchly reaffirmed its convictions in opposition to all war as the instrument of capitalistic imperialism. The Socialist Party declared its official policy in regard to the war to be uncondltional neutrallty. In September, 1914. the PSI issued a statement explaining its position. Reportedly, the statement was prepared jointly by Turati and Mussolini. the leaders of the two internal factions within the PSI, and represented the substantial consensus on the issue within the party membership.

This high degree of cohesion shown by the PSI lasted about three weeks. Mussolini grew restless under the bonds of the same policy of inaction toward war advocated by Turati, Giolitti, and the Church.ss The Socialists were not advancing their interests by mere neutrality. Faced with the dilemma of reconciling his previous position, that war was utterly incompatible with Socialist principles, with a desire to have the PSI take a more forceful policy, Mussolini reconsldered the causes of war. He accepted the distinction between kinds of war drawn by Jean Jaures, the French Socialist whose party had voted to support its government in the war effort. Mussolinl concluded that there were two kinds of war: not only was there war for conquest. which Sociallism must condemn on principle, but also there was war to end wars, which Socialism should support and carry to the finish. Mussolini judged the war 
of 1914 to be of the second kind, and therefore urged the PSI to take up the policy of intervention and to fight, in the name of Socialism, to "end all wars."34

The other Sociallst leaders reacted immediately to this deviation from the party position. They had just rationalized their expulsion of the Minimalists' legalitarlan group in 1912 for urging the proletarlat to support the State when it was involved in the dangerous enterprise of war, on the grounds that any support of war was heretical to Socialist principles. Although Mussolinl's reasons were different, he still asked the workers' movement to support war. which defined in Socialist terms could only mean supporting the imperialist efforts of a capitalistic, bourgeols regime. This was intolerable to the socialist leaders: they promptly expelled Mussolini from the PSI. The editorship of AvantI! passed into other hands. 37

Scarcely subdued by hls expulston. Mussolini lmmedlately began to mobilize support for his position of intervention in the war. He could not forget his rejection by the Socialist leaders and attacked them in his new daily paper. Il popelo d'Italia. He declared his intention to seek the favor of the proletarlat, and thereby to "raise the standard of schism" among the followers of the PSI. ao

A group on the extreme left within the Maximalist wing did follow Mussolini from the PSI. This loss affected the party more in terms of quality than in quantity; the group 
was small, but it represented some of the most vociferous elements clamoring for direct action in the party. It was composed of the frustrated workers and peasants from the Parma and Ferrara regions, young men attracted by the excitement and glory promised by Mussollini's bold proposal and men generally discontented with their lot and with life in general.as

With the expulsion of Mussolini, the PSI had not severed its two most widely-differing factions, the thoroughly legitimatist group among the Minimalists, which renounced the Marxian theory of class war and the inevitable demise of bourgeols institutions. and the group which urged war, revolution, and violent action indiscriminately of Marxian purpose within the Maximalist wing. These excisions from the party served only to confirm, for the body of the party membershlp, the validity of their traditional beliefs. The remaining section of the Maximalists retained the leadership of the PSI under Lazzari. They and the attenuated group of Minimalists found common cause in protesting the European war as intolerable for the international brotherhood of workers. But even their agreement on this general protest was based partially on different reasons. While Lazzarl and the Maximalists steadfastly asserted their opposition to the war on Marxist grounds. Turati, speaking for the largely Minimalist Socialist Parliamentary Delegation in the Chamber, argued against Italy's intervention in 
the European war because it would result in unavoldable paralysis of the nation's economy and damage to its culture. Turatl's argument reflected concern for the preservation of the nation's existing order, In contrast to the Socialists' stated aim of destroying that form of economy and creating a new culture. The fundamentally different commitments of the two groups within the party appear even at this point of ostensible unanimity.

The policy of protest against the war, however, was the extent of offensive strategy proposed for the PSI by the party leaders in regard to the event of war in terms of its pursult of the social revolution. Not even the fact of Italy's actual entry into war in May 1915, shook the PSI in its convictions. Instead. the party solemnly rededicated its efforts to maintaining its Marxist ideals. Obliged to define some policy in political action with regard to the nation's war enterprise, the PSI stated its official position as being "neither to adhere nor to sabotage." 40

This program was, in itself, a compromise policy. The Socialists refused to support the war on the grounds that it was the product of the capltallst system: yet the PSI would not hinder its prosecution or take any intentlonal measures which would harm the national state in its efforts. Given its political position, this was about the only policy the Sociallist Party could take. To support the national war effort would have meant renunciation of its Marxist 
principles, whlch the party had just affirmed twice at painful cost. The PSI was too comnitted to Marxist princlples to deny them, at thls point. with regard to the fact of war. Moreover, the war was not popular in the nation: other groups including the Church, were as openly opposed to it as the Socialists.41 But non-support of the war effort and a deliberate attempt to undermine the national state. partlcularly when it was already in danger, were altogether different. The latter action would no doubt have allenated the PSI from natlonal life altogether. In defining a program for action. the party leaders were bound by another consideration. They wanted, above all. to maintain the following they had secured: they did not want to lose any other portion of the "working class movement." The PSI now received Its support principally from two elements in the population: the industrial workers of the North and peasants. The party's strength among the latter group was concentrated largely in the Po Valley. Uncultured and uneducated, these groups could grasp the significance of war only as it impinged on their personal or local affairs. They supported the PSI as the party of the working class. Different reasons for supporting war or distinctions between various kinds of war had no meaning for them. Glven the nature of thls audlence, class solldarlty was the most potent policy the PSI leaders could advocate and still maintain these groups' support. 42 In essence, the 
party had conflrmed the continuation of its position in neither being wholly for or wholly against the existing order. This program offered, however, no speclfle. constructive policies for the establishment of Sociallst institutions in Itallan society.

By assuming an official role of protest against the war. the PSI acquired new stature. As the party continued its criticism of the war policy and of the government for executing it, it publicly disassoclated itself from the initlation of the war or any of the sacrifices and bad conditions imposed by it on the population. Having denied any responsibility for the war's prosecution, the Socialist leaders offered their princlples as the only sure and humane basis for peace. The population, growing increasingly discontented and dissatisfied with the strains Imposed upon them by a war which they had not really wanted from the start, became more and more receptive to Socialist claims. The Socialist Party gained new respect and recognition. They addressed the nation and Europe with increased authority, speaking as the voice of the masses.43

The formal organization and activitles of the PSI as a political party, however, had been disrupted during the war years. No Congresses had been convened: the official channels of communication from the Executive Committee to the sections and between the various sections had broken down. Groups of Soclalists developed their partlcular ideas 
about speclflc party practlces and values in relative isolation from each other as the conditions of war continued. ${ }^{44}$

Turatl's group defined a remarkable set of reforms deslgned to correct baslc economlc and polltical problems in Itallan soclety, which it proposed the PSI initlate through Parllamentary legislation. These reforms Included provislons for: 1) a republican constltution, 2) a singlechamber government with universal suffrage, 3) the election of magistrates and high offlcials, 4) social insurance, and 5) a program of public works and land reclamation.

Lazzari stlll held the position of nominal leadership in the party. He and his followers strlctly malntalned the polley of workers' solidarity in the class war. A new dlstinct group had formed on the extreme left of the Maximalist segment. This was the circle of young men who had formed thelr conception of a workers' party program around the Ideas of Lenin. They had become Impatlent with the vaclllations and Internal factionallom of the PSI. They consldered its old leaders inept and 1 ts program Indecisive and ambivalent. They were fully convinced of the need for destroying bourgeols institutions, verifled by the tanglble evidence of existing social and economic conditions in Italy. They urged the Soclallsts to use the events of European war as the premlse for radlcal action agalnst the bourgeols state. 
The PSI's organizational apparatus for pursuing a definite program in political action had gradually become more a nominal association of separate groups than an efflcient, cohesive party. Two events in late 1917 illustrated very clearly the lack of agreement on basic principles and prospective action in the PSI. In October, the Italian milltary forces suffered a defeat by the Austro-German armies at Caporetto. The defeat was virtually a national disaster. It shook the confidence of the entire nation and forced a recognition of the possibility of defeat upon the people with terrifying reality. Only a few weeks later came the news of the Bolsheviks' seizure of state power in Russia. The extreme wing of the Russian workers' movement had succeeded in carrying out its revolution. Italy's critical military defeat at Caporetto forced the Minimalist Socialists to reconsider their position in regard to the war. To the MInimalist leaders, support of the national war effort now became a question of protecting the freedom of operation the Socialists enjoyed under the Italian national state. The Minimalist leaders foresaw the results of natlonal defeat to be not the demise of the bourgeois national government, which would facilitate the Socialists' assumption of power, but the subjugation of the Italian workers as well as the rest of the population to the terms of defeat imposed by foreign conquerors. Therefore, they changed their position and called on the PSI to support 
the nation in its dangerous enterprise. ${ }^{45}$ This shift in position was very slgnificant. It admitted the Socialists' dependence upon the national state for protection of its existence. Also it took cognizance of the fact that even at the polnt of the fallure of bourgeols institutlons, the workers' movement was not strong enough to assume power itself. When the Bolshevik Revolution occurred a few weeks after Caporetto, the Minimallst group regarded the event with abhorrence because of the Bolsheviks' use of violence. They felt this method of gaining power, besides belng barbaric, violated the essence of Socialist principles which recelved their validlty from the fact that the Instltution of Socialism would be the legitlmate wish of the immense majority. They recognized the establishment of social control by the workers' party in Russia, but did not commend the means as a model for other workerg' movements, least of all for civilized Italy.46 The change of social order was no miracle and could be achieved satisfactorily only over the protracted perlod of time needed to accomplish all the tasks involved.

The Maximalists, however, regarded Italy's defeat at Caporetto as a slgn of the bourgeois state's near collapse in accordance with the Marxist prophecy. They interpreted the event as encouragement for the PSI to redouble its efforts in the class war, as the bourgeols institutions were weakening and the success of Socialism was near. 
When the Maximal ists learned of the Bolshevik Revolution, they rejolced without quallfication. The prophecy had been fulfilled in Russia. Surely fulflllment was close at hand for the Italian working class. The Maximallst leaders urged the PSI to follow the inspiration of the Bolsheviks' success and to intensify its revolutionary propaganda and preparation among the Itall an working forces to hasten thelr dlrect selzure of power.47

The new Leninist-oriented group, on the left, in the Maximalist wing, interpreted the nation's defeat at Caporetto as sure evidence of the weakness of the bourgeois state. The PSI's pollicy, then, should unquestionably be to take advantage of this weakness of the bourgeois state and work for its complete defeat in order to establish workers' control of the society.

This group greeted the Bolshevik Revolution as representing the complete success of a working class movement's struggle to gain power. Not only did the new faction look upon the Russian movement's revolution as encouragement to the workers' struggle in all countries, but also as the successful model after which the workers' parties should pattern their own strategy. The group of young Leninists, Antonio Gramsci, Amadeo Bordiga, Angelo Tasca, and Palmiro Togl latti urged the PSI to drop what they saw as all other distracting and enervating pollcles such as parliamentary cooperation. and follow the example of the 
Bolsheviks. 4 a

Thls was the internal condition of the Soclalist Party when the war ended in 1918. The leaders were divided into three distinct groups, each with its own speciflc program for PSI action and each contradicting to the others. Furthermore, each group addressed its appeal for Soclalist actlon to a separate soclal element. Turatl and hls companions spoke for Socialist actlon in the Chamber of Deputies; Lazzari and Bombacci urged insurrection among the workers in the streets, and Gramscl. Bordlga, Togllattl, and Tasca called for a select group of men who would be capable of executing the revolution against the existing institutions of social power. The unifying ties between these dlfferent groups were the general hope of transforming the lot of the working class and the dedication of their efforts in behalf of the whole of the workers' element in Italian society. 


\section{Part III. Post-war Demands for Soclallst Actlon}

After the war ended. the PSI found itself in a unique position for political action. Economic and social conditions of the country were ones of grave disorder. The strains of war, coupled with the demands of post-war rebuilding, rehabilitation of veterans, widows, orphans, and reconversion of the economy and facilities of the society to peacetime operation posed an immense task for the stablest of governments. The Italian democratic government was not functioning in the most çapable manner. People were discontented and disillusioned over the results of the seemingly fruitless war undertaken by the government, and by government confusion and inaction in the chaotic post-war situation. The PSI had maintained its role of protest against the government's policy throughout the war, and now offered the single alternative for political action which was not associated with the war. Large numbers of Italians turned readlly to the hope and alternative offered by the Socialists. This wide response to Socialist claims was not a specific commitment to Marxist principles for the larger part of the population, but rather demonstrated a general discontent with the present situation and a general wlllingness to support new leadership and a new policy in 
government.

The national electlons in November, 1919, the first since the war had begun, confirmed the Socialists' new strength. The PSI received the largest single percentage of the votes cast--32.3\% of the total. Thls vote entltled the party to a plurality of 156 seats in the Chamber of Deputles.48 This great popular shift to the Sociallsts made It by far the strongest party in the country. The next largest was the Cathollc Popular Party, appearing for the first time on the ballot in 1919, which won 100 seats in the Chamber. But the Soclalists did not recelve a clear majority of the votes cast and therefore could not legitimately claim the right to enact their program in toto. Consequently, the PSI again faced its recurrent problem of political action. The thousands who had come to support the party demanded and expected that the PSI do something in regard to the shortages of food, jobs. inadequate equipment, spiraling prices, and worn-out public facllities. Bound to refrain from lllegitimate means of social action, the PSI did not have majority support within the society for the legitimate enactment of its program. but it was officlally committed to the enactment of nothing less than a complete transformation of the social order. The urgencles of the situation compelled the party to act or lose contact with the wave of popular support it had recelved at the end of the war. 
Each of the three groups within the leadership of the party advocated a policy for the PSI which was exclusive of the other two groups' policles. The largest number of the party's old membership, the group from the Maximalist wing, remained committed to the old program of rejecting bourgeols Institutions and continuing to bulld, outside of them, the evolutionary workers' force whlch would legitimately assume social power.

Turati's group, the Minimalists, continued to insist on the renunclation of violent means by the party and on the exercise, whenever advantageous for the workers, of legitimate means to advance their cause. In this way the PSI would continue to build its majority within the society and soon would have legitlmate control of the soclety by the will of the majority.

The group of young Leninists urged the PSI to repudlate legitlmate and democratlc methods altogether in pursuing the workers' interests, and to afflliate with the Communist International. accepting its program and observing its discipline in the local Itallan situation. They felt that the PSI should undertake in political actlon only those projects which would contribute to its ultimate goal, seizure of total power. With the largest segment of the party's membership affirming the old Dual Program, the PSI confirmed this policy as its official program when its delegates convened in 1919 at the first Party Congress since 
the beginning of the war.

The PSI organization for securing polltical power was badly fractured. The three leadershlp groups were committed to three particular sets of principles and programs which they could not compromise. The effective base of support of each group was distinct from the other. Popular support for the party rested on the general deslre for change promised by Socialist ideals. The party had not resolved its basic conflict between legitimacy and total social revolution in political action. With serlous internal disagreement in the party organization, the increasing pressure on the PSI to take action in order to demonstrate the validity of its doctrines placed the party in an impossible situation. The movement as a whole could no longer withstand the strain. 
CHAPTER V

THE DISINTEGRATION OF THE

\section{ITALIAN SOCIALIST PARTY}

The peak of the pressure exerted upon the socialist Party for some klnd of polltlcal actlon came in the fall of 1920. Up to this time, the party had been steadily increasing its following among the population. In the summer of 1920, the PSI claimed a quarter of a million members and the support of $3.000,000$ workers organized in politically affiliated Chambers of Labor.' The party had progressed significantly also in its work of organizing cooperatives and new syndicates of workers. In September 1920, two events occurred which required declsions on political action. But, since the party as a whole could arrive at no common policy, the distinct segments within it reached decisions based on their own principles and split, each claiming to be acting alone in the "true" interests of the Italian working class.

In late August 1920, after a perlod of prolonged. unsuccessful negotiation between the metal industry's management and the metalworkers' union over wage increases and workers' benefits, the metal workers' union moved to occupy the factories. The union intended to limit the 
factory occupation to the metal industry and asked only the granting of its particular requests on wages and beneflts from the industry. Discipline among the union members in response to this directive was strict, and the movement was successful. Large factories, key to the metal industry, were occupied by workers first in Mllan and Turin. The metalworkers' occupation spread throughout the country. The State, afraid of fanning bloody civil strife, refrained from blockling the spread of the occupation or forcing the workers from the barrlcaded plants. Glolittl, again Prime Minlster, announced the government's neutrality in regard to the dispute.

The issue created by this event was not confined to the workers' movement. Management of the metal industry did not immediately capitulate to the workers' demands, and the question arose whether the occupation should be extended to other industrles in a bold workers' seizure of control of the means of production. The PSI, the party of the working class striving for revolution and control of production, confronted a situation which was extra-legal, but also one of potential revolution.

The Socialist leaders were badly divided over which course of action to take. The Maximalists fervently urged the PSI to seize the opportunity and carry out the workers' revolution. The state was impotent and Socialist popular support was at its highest point. They asserted that the 
prophesied time for revolution had come. The Minimalists, however. worried about the practical aspects of workers' control of the soclety at this time. Would the workers be able successfully to plan and administer production in the factories? Would they be able to carry out trade negotiations and to master the technical knowledge required? or would the occupation collapse in a farce of inefficiency and incapability, thus seriously disordering the functional operation of the society and discredlting the workers' movement totally in the eyes of the population? The party leaders called a special congress on the issue and engaged In exhaust Ing debate. They flnally requested a special session of Parliament to deal with the issue. The irony of the Socialists" appeal to this "useless, bourgeols institution" to arbitrate a dispute between workers and management illustrates polgnantly the incapability of the party to deal with the situation from the basis of its own strength.

Officially, the PSI extended its full sympathy to the metal workers in their struggle, but resolved to limit the occupation of the metal industry. In practice, this double policy accomplished nothing for the PSI. Without help from the Socialists, the metal workers could not possibly hold out for essential changes in worker/management relations, and their discipline began to crumble. On the other hand, the government and the industrialists bullt up a bitter resentment agalnst the Socialists, who continued to 
propagandlze for the metalworkers "Insurrectlon." On the basis of this experlence, these two important social groups grew determined to squelch the Socialist threat to civil peace and the exlsting order.

The events of the occupation itself settled with the passing of time. When the militancy of the workers had dissipated sufficiently. Prime Minister Giolitti Intervened and proposed terms for settlement of the dispute. Management accepted them; the metal workers' federation ratified them; the workers left the barrlcades and returned to their jobs. Ostensibly, the government's terms Included concesslons to trade unions' power. The most widely acclaimed of these was the representation of workers' organizations, together with industrlal organlzatlons and technlclans, on a council newly-established to make recommendations for government legislation on problems in the development of production and worker/management relations. Actually, the Increase granted to workers' influence or control in the process of production was negligible. The PSI had shown only disorganlzation and confusion in a propitious moment for practical action. From that point on, popular support for the Sociallsts began to fall away.

Almost immediately after the PSI failed to turn the factory occupation to its favor in political action, it confronted another event which required a decision on the essentlal character of the party, this time in regard to the 
primary values of the party and the nature of its internal organization. The Communist International lssued a list of condltions, Twenty-One Polnts, whlch a workers' party had to fulfill in order to gain admission to its organization, thus qualifying as a truly revolutionary party. Essentially, the I I International's standards required that workers' partles: 1) abandon all legltimist, reformist characteristics, activities, and segments of their memberships; 2) accept the aims of the workers' revolution for the International proletariat and dedicate their efforts unquestioningly to fulfill this aim as directed by the III International, whlch took as its guide the successful example of the Russian Bolshevik Revolution; and 32 in recognition of its new character and calling, change its name to "Communist." =

This proclamation provoked serious internal rifts in the Sociallst Party. It offered enlistment among the ranks of the revolutionary elite, guidance from and association with the men who had executed the most successful workers. revolution, and the prestige and recognition of the Itallan party's true revolutlonary character among the workers. parties of other nations. The price demanded the repudiation of the PSI's previous thirty years of history as the Itallan party of the worklng class. It required the rejection of associations formed. and practices engaged in, over those last thirty years. It meant the expulsion of men 
who were sincerely devoted to the improvement of workers: conditions and who had spent their lives in the service of the PSI. It required, in essence, the rejection of one of the party's founding principles--the aim to achieve social transformation through legltimate means.

The party called a congress in January, 1921, at Leghorn, to act officially on the issue. The three factions within the PSI reacted to the ultimatum of the III Internatlonal In character with their prevlously stated positlons. The Minimalists, led by Turati and Treves, advocated that the PSI refuse the offer of the Comintern program flatly. To them, it did not represent the true Socialist principles of mature effort to improve the economic and social conditions of the proletariat, and to develop the workers' political and moral capaclties. The program sanctioned violent means which true Socialists could not condone. In thls resolution, the Minimalists received the support of the majority of the Socialist deputles in Parllament, the offlclals of the General Confederation of Labor and the cooperative organizations.

The group of Leninists on the extreme left, now called the ardine Nuovo (New Order) group because they had founded their own journal by that name in Turin, immediately recommended that the PSI accept without qualification the terms of the Comintern program. They had been won to Lenin's efflclent, disclplined conception of a workers' 
party, and now considered it impossible for a "genuine" workers' party to act In any other way. To them, It was Imperative that the PSI drop its legltimlst elements if it sincerely sought to carry out the workers' revolution.

The largest, and most traditlonal, portion of the Maximallst wing, now called the Center, presented a compromise solution. They desired that the PSI accept the principles of the III International's program as a revolutlonary party, but to refuse some of the condltions. For example, the Centrists would refuse to expel a slgniflcant portion of the party members, the MInImallsts, or to accept direction from the Comintern in local party affairs without question. Thls group, led by Glacinto Serratl, felt it unnecessary that the PSI should have to prove its revolutlonary character, since it, alone of all European Soclalist partles, had malntalned Its opposition to the natlonal war policy throughout the World War.4

After a long, intense, heart-rending debate at the Congress of Leghorn, the lssue came to a vote. The Center motion of "unitary communlsm" recelved the majorlty and became the officlal program of the party.=

The Leninist fraction had stated Its terms in language too strong to be retracted. After the majorlty vote for the Center motion was announced, the Ordine Nuove leaders refused to accept it as thelr program. They clalmed that "the majority of the Congress, by Its vote, has placed 
Itself outside the Communist Thlrd International." With thls declaration, the Leninist delegation abandoned the PSI Congress and, on the next day, January 21, 1921, in another hall In Leghorn, It offlclally founded the Itallan Communist Party.

The forceful distinction between "revolutionary" and "non-revolutionary" working class parties defined by the Comintern had compelled the long-dreaded schlsm within the PSI. This division was caused by no expulsion, but by the voluntary separation of one wing from the body of the party. The loss of the Communlst faction did not affect the PSI greatly in terms of numbers, but it did mean the loss of one of the elements in the party that urged a decisive, specific program of action. It meant also the open repudiation of one of the PSI's baslc goals by a qualltatlvely slgnlflcant element of the working class movement, the young intellectuals.

The remalning body of the PSI accepted the Centrlst program as voted at Leghorn and continued its legitimate, but revolutionary policy. Prospects for increasing its soclal power worsened steadlly however. Although the PSI considered Itself an adherent to the princlples of the III International, this organization did not extend membership to the PSI. Rather, it admitted to its exclusive circle the Communlst fraction of the Itallan working class movement, the newly-formed Itallan Communist Party (PCI). 
Second, the social situation in Italy at this time was deterlorating steadlly. The problems of unemployment, rising Inflation, low wages, and a mounting national debt contributed to general social confusion and disorder. The Chamber of Deputies, the legitimate ruling body of the society, was hopelessly fragmented by Catholic, natlonallst, liberal. and Socialist blocs. No single delegation was large enough to command a majority in order to enact a forceful program of administration to deal with the multiplying problems. The Sociallst delegation, the largest bloc in Parliament, refused to particlpate in any bourgeois coalltion and continued to obstruct any government measures proposed. It thus contributed substantlally to the paralysis of Parliament.

The Socialists continued to instigate strikes and other hostl le demonstrations agalnst these bad conditions and the bourgeois government, but themselves produced no practical changes or initiated any constructive action. In fact, their strikes and demonstratlons were disorganized and carrled out in a spontaneous, sporadic fashion, rather than directed toward a specific, purposeful end.a As a consequence, the Sociallsts' popular following began to decline, and the liberals in Parliament and the industrialists became more convinced of the Socialist threat to the social order and more commltted to thelr destruction.

At thls time, another movement capltalized on the 
Sociallst misfortunes and struck directly at the Sociallst base of power, the masses. The Fascists first won support from the enemies of Socialism, as they focused their polltical activity on ellminating the Socialist threat to the clvil order. The Fasclsts intensifled thelr efforts to win the support of the masses, compiling a record of unpunished illegal acts carried out with the well-known accoutrements of clubs, black shirts, and castor oil. = They burned the buildings of Socialist headquarters, destroyed the local Avantil presses, intimidated Sociallst personal 1ties, and even rousted the Sociallst clvlc government from office in Mllan.

The Socialists refused any organized retaliation against these outrages on the grounds that they engaged only in legitimate action and denounced all violent methods. Still. the party refused to recognize any threat to its assumption of power but the bourgeois state. The Socialist deputles in Parllament continued thelr obstruction of the bourgeois government's action and accentuated the weakening of this government's maintenance of legal order.

The beginnings of the shift in the electorate away from the Soclalists were manlfested in the results of the elections called by Giolitti in May 1921. The Socialist percentage of the total vote fell from 32.3 percent (1919) to only 24.7 percent. The Socialist contlngent in Parliament dropped from 156 to 123. The Fascist Party rose from 
previous marginal importance in Parllament to the role of a member of Giolltt's "national bloc" with thlrty-five seats. In the same election, the new Communist Party showed its entrenchment in national 11 fe by winning fifteen seats.10

The Minimalist element in the party became increasIngly alarmed at the mounting Fasclst 11 legalltles and urged that the PSI cooperate with the bourgeois government to put down Fascist lawlessness. The main section of the party, again called the Maximalists, however, regarded such a measure as an unholy violation of Socialist principles. This group. led by Serrati, was chiefly concerned with wresting recognition from the Communist International of the PSI's true revolutionary character. In fact, in an attempt to convince the III International of this truth, it issued a statement condemning collaboration between the Soclalist Party and bourgeois parties in Parllament. 12 The III International still refused to recognize the PSI as meriting membership in its association, however, on the basis of continued Minimalist participation in the party.

Mussolini noted at this time the possibllitles offered for the advancement of his movement by Socialist inertia. He observed that continuation of Socialist policy of refusing to collaborate with bourgeols partles in parliament. while maintaining strict observance of legitimate methods in social action, rendered the PSI, the strongest 
single force in the nation, powerless to obstruct the Fascists" bid for power. Mussolini foresaw that "the National Right, in which the Fascists are the majority, can be the arbiter of the life or death of governments; no government can govern without 1 t. We therefore declare ourselves," he continued, "particularly pleased. Fascism now has before it a great field of possibillties; it can do great things, not gestures but deeds, not mere words..."12 With the way thus facilitated, Mussolini opened full attack on Italian social and legal institutions in his quest for power. Fascist activity intensified and its areas of social control steadily increased. Parliamentary action was reduced to argumentation.

As the pressure of the political crisis grew more acute, the Minimalist deputies in the PSI finally broke with the Party Executive and openly gave advice to the bourgeois State on the policies of governing. Turati set aside his lifelong principle of non-collaboration with bourgeois partles and answered the KIng's summons for consultations regarding the formation of a new Cabinet after the fall of the Facta Government on June 15, 1922.

The Party Executive, led by Serrati and representing the rump Maximalist sectlon. Immediately selzed upon this act as one transgressing the sacred revolutionary principles of Socialism and as grounds for expelling the Minimalist element from the party. The Party Executive repudiated 
Turatl and hls companlons in the following day's Avantl!, charging that by thelr political talks with the monarch, the Minimalists had "with their own hands, shattered the unity (of Sociallst princlple) of whlch, until yesterday you would have had us belleve you were the tenacious and ardent supporters."1a At the following PSI Congress in Rome in October 1922, Serratl succeeded In mustering a majorlty vote for expelling the Minimalist wing from the party, hoping, by this act, to demonstrate the PSI's revolutionary character to the III International. The Maximallst margin in this declslve vote was very narrow, 32,000 votes over 29,100 for the Minimalist motion, which proposed that the PSI as a whole support the parliamentary regime against Fascist efforts to destroy 1t. Nevertheless, the Maximalist vote carried and the Minimalists were exorclsed from the PSI.14 The proud, long-vaunted unity of the Itallan working class party lay fragmented in three autonomous partles. A small but firmly committed segment of Leninist revolutionarles made up the PCI. A signlficant portion, the Minimalists, formed the Unltary Soclalist Party. They inad not relinquished their Ideals of social change for the benefit of the working class, but could not deny merit and usefulness to the existing bourgeols institutions. The body of the PSI, very much reduced in size, remained commltted to the principles of class war by legitimate methods. 
Maximallst group expected, the expulsion of the Minimallsts from the party only helghtened Its confusion. The III Internatlonal, Instead of welcoming the PSI Into Its ranks as the officlal representative of the Itallan working class, urged the Soclallst Party to fuse with the PCI, already an authorlzed section of the III International. The "purlfled" Sociallsts faced a new tension. They had not realized that separation from the reformist Minimalists would bring the PSI closer to another threat to 1 ts 1 dentlty, fuslon wlth the Leninlst PCI. To recelve no merit for 1 ts long tradition of serving the Itallan working clasg and to be asked to renounce 1 ts name and symbols for fusion with the coldly theoretlcal, whlch the Minlmallsts saw as only destructlve young PCI proved angulshing and frustrating for the PSI leaders. In addltion, the mass of the PSI membership was not willing to use violent action indiscriminately, but were commltted to assume power when the revolutlonary majority had been bullt.

In domestic politics, the Fascigt offensive againgt the legal order and parllamentary government became bolder and bolder. The editorial offlces of dvantl! were burned in Rome, but PSI leaders st 111 refused to recognize any serlous threat to their existence except that presented by the capltallst classes. They were preoccupled at the time with the task of defining their status as the only party representing the true revolutlonary interests of the Itallan 
working class. Two nights before the "March of Rome", PSI leaders boarded the train to Moscow to attend a Congress of the III International in order to plead the party's new case for recognition.

The next events in Italian history are well-known. Mussolinl's men encountered no resistance in their occupation of Rome. The Facta Cabinet resigned; the King invited Mussolinl to form the new Cabinet. Fascist leadership continued to expand its control in the society, assisted by the Fascist squads. Popular support turned to the Fascists. Following Mussolini's accession to power, the PSI suffered almost continuous attacks. Fasclst squads burned and wrecked Socialist buildings, intimidated party members and broke up Socialist-affiliated cooperatives. The party's membership declined, and its local organizations found it increasingly difflcult to carry on propaganda or polltical operations. Its influence in social affairs diminished rapidly.

The leadership of the Soclalist Party foundered with no clear sense of direction under the Fascist attack and the II International's rejection of its revolutionary validity. Serrati, chairman of the party, appeared increasingly muddled and unsure of the PSI's actual identity.

At this point, a new figure rose to leadership in the PSI fragment. Bringing fresh energy and dedication to the workers cause. Pletro Nennl assumed the leadership of the 
party in August 1923, expelling Serratl from membership. Nenni redefined the purpose of the PSI in its tradition of a working class party striving to build a legitimate proletarian majority in order to institute the socialist order. The now-diminished group of manual workers within the party, the segment which had originally formed the majority, continued their alleglance to this conception of Sociallsm and purpose for a worker's party. It was this conception which sustained, and fell helr to, the tradition and symbols of the PSI's previous thirty years of existence as the Italian workers' party. The Italian Soclallst Party that emerged from the crises of 1919-1923 reaffirmed the principles of legitimate revolution. The political stringencles of fascism curtalled activities and opportunitles for action by it or any other party until the Fasclst suppression of all other political activity in 1925. This remnant of the Socialist Party, however, maintained its conception of political action through underground activitles during the twenty-flve years of Fascism, and is essentlally the same PSI that is operating in Italian polltics today. 
CHAPTER VI

CONCLUSION

The Italian Socialist Party (PSI) had started to develop the same bifurcation that was common to the other European Socialists who accepted the formula of legitimate revolution. Under this formula it passed through the stages of unification, establishment as a constitutional party using legitimate means to secure the revolution in economic and social arrangements, and entrance into the field of politics. During the decade of the 1900s, when the Socialists first participated in national political life as a recognized party, serious differences in theory developed as evidenced by the Minimalist and Maximalist programs. These led, in turn, to differences concerning strategy and tactics, as illustrated by the election-oriented policy of the reformists and the strikes and direct action, with repudiation of parliamentary reforms, advocated by the revolutionaries. In fact, these differences very nearly led to division of the two main factions into separate organizations in 1904-1906. Only Serrati's impractical but emotionally-appealing centrist formula held the organizational unity of the party together at that time. For a brief period, from 1908 to 1911 , it appeared as if the 
degree of conflict between factlons was diminishing within the party, with the reformists gaining ascendancy and gradually leading the PSI as a whole to an acceptance of constitutionalism as its primary value.

But the superflclallty of thls tendency became apparent over the crisis of the Libyan War, when the democratic reformists were ousted from the party upon their refusal to break the attachment the PSI had established with the democratic government, despite the government's pollcy concerning imperialistic war. The revolutionists assumed control of the party at this juncture, but the shallowness of their support within the party was demonstrated by the expulston of Mussolini over his advocacy of a war policy in 1914.

These two crises put the party fairly well back to its old formulation adopted at the Congress of Genoa in 1892-constitutionalism in political method, but no cooperation with the bourgeols parties or government, and revolution in the economic and social fleld, but no use of force or violent means. The majority of the party reaffirmed its old beliefs and rejected the possibilities of either constitutionalism alone or revolution us!ng violence as aberrations from the faith. In doing so, it withdrew from making any decision on the crucial issue of politics in the country at the time.

The PSI remained steadfast in its official abstention 
from elther support or sabotage of the governments' war policy, and the fact that it was able to do so illustrated the party's lack of involvement in national political life. When the events of the post war situation provided opportunities for the PSI to take either the constitutional or revolutionary route to political power, either of which would have required the rejection of the other for success, the majority of the party falled to see any real conflict in values between the two kinds of action. The majority of the party's supporters refused to abandon the old formula of constitutional revolution. They kept the original faith and would tolerate no deviation from it. The theory was not questioned; only the political situation was not yet right for its success. Cleansed of deviations to Left or Rlght, the Itallan Social ist Party rededicated ltself to its original purpose of constitutional revolution. The ban on all non-Fascist political activity came in 1925 with Mussolini's assumption of total political power in the country.

Forced underground by the Fascist ban of all nonFascist polltical partles in 1925, the PSI attempted to carry on at least token activity in exile. During the troubled period from 1925 to 1930 , the Socialist leaders indulged in considerable re-examination of their past pollcies, which had led to this loss of freedom, and in searching for possibllities of regaining freedom of 
political action in their country. After much introspection, the Socialist leaders agreed that the major purpose of all Socialists must be to create and sustain unity of the working class, both for its eventual assumption of political power through democratic electlons and for immediate purpose of fighting against Fascism.

In conclusion, most of the socialist movements found the old theory unworkable in their political conditions. To carry out an effective constitutional program for reform, a Sociallst movement had to secure support from sources outside the proletariat, too. Or, to institute economic collectivism in the most expeditious way, a party had to dispense with the conventions of constitutionalism, and utilize skillfully all of the opportunities avallable to a minority party for the conquest of power. Support of the masses was sought in this method, but as support or toleration, rather than participation in the actual assumption of power. The theory of constitutional revolution became too simple for the working classes in the European countries. In the conditions whlch precipitated the decline of class consciousness, the masses did not vote automatically for the Socialists' program of revolution, but supported other loyalties in politics: religion, nationalism, and individual liberties.

A simple program of economic and social revolution failed to receive a constitutional majority in any European 
country, and became increasingly removed from the central political lssues of the country. Measures either more pertinent to national political life or more effective in galning political power, had to be adopted for successful political results. 
ENDNOTES

CHAPTER I

'Peter Gay, The DUlemma of Demacratle Soclallsm (New
York: Columbla UnIversity Press, 1952 ) 10.

zPeter Gay, op. clt., pp. 238-244.

oCarlo Sforza, Centemporary Italy (New York: E. P. Dutton and Co., Inc., 1944) PP. 149-153.

${ }^{4}$ Chr lstopher Seton-Watson, Italy from Liberallsm to Easc lsm: 1870-1925 (London: Butler and Tanner Ltd., 1967) pp. 157-161.

shrlstopher Seton-Watson, op, cit., pp 157-158.

-Carlo Sforza, op, cit., pp. 159-161.

'Christopher Seton-Watson, op, clt., pp. 67-72.

Ibid, pp. 157-160.

Ibid, pp. 109-110.

10 Peter Gay, ep.cit., pp. 268-271.

${ }^{1}$ Christopher Seton-Watson, op, cite, pp. 157-161.

1 zpeter Gay, op.clt., pp. 100-101.

1 Ibid, pp. 274-279.

${ }^{14}$ Christopher Seton-Watson, ep. cit., pp. 600-601. CHAPTER I I

'Robert Mlchels, A Critlcal Study of the Itallan Socialist Movement (Firenze, Le Voce, 1926) 219-222.

2Robert Mlchels, op, elt., pp. 126-127.

oDenis Mack Smith, Italy (Ann Arbor: University of Michlgan Press, 1959) 173-175.

aDenis Mack Smith, op.cit., pp. 173-175; 192-197. 
sRobert Mlchels, op, cit,, p. 163.

Iblde, p. 169.

Ibld.

Ibld,. p. 191.

Ibld.

latbid., p. 176.

12 Ibide, p. 193.

12 Wayl and Hilton-Young, The Itallan Left (London: Longman's Green and Co., 1949) 39.

1 Ibid. Pp. 42-43.

14 Robert Michels, op,cit., p. 208.

1 sWayland HIlton-Young, ep, clt., p. 39.

1 SRobert Mlchels, 오. cit., p. 193.

CHAPTER I I I

${ }^{1}$ Robert Mlchels, 오, cit,, p. 208.

zlpld., pp. 225-26.

ILlvio Marche HI. The Economic Revival of Italy (Turin: Editrice Torinese, 1918) 13.

"Robert Michels, op.cit., pp. 225-226.

Glovanni Glolitti, Memorles of My Llfe (Monza: Garzant I Editor, 1945) 63.

¿Way land HIIton-Young, ep, cit., pp. 54-55.

>Robert Michels, op, cit., p. 251.

Ibid.

Ibid., pp. 223-24.

10 Ibide, p. 221.

11 Ibide, pp. 219-222.

12 Ibid.

1 Ibid., p. 226. 
14 Ibide, pp. 213-217.

CHAPTER IV

'Robert Michels, op.cit., p. 286.

zWayland Hilton-Young, op. cit., p. 46.

Ibid., p. 35.

4 Ibid,, p. 59.

sIbide, p. 26.

-Robert Mlchels, op.clt., p. 243.

Ibld., p. 254.

Ibld., p. 256.

Ibld., p. 262.

10 Ibld., pp. 262-264.

1 Ibld., p. 262.

12 Ibid., p. 243.

sibld.

14 Ibld., pp. 297-298.

1 Ibld., p. 303.

$1 \triangle I b \mid d .$, p. 303.

$1>$ Ibla.

10 Wayland HIlton-Young, op, elt., p. 59.

1 Ibld.

20Robert Michels, op. clt., pp. 265-269.

21 Ibld., p. 269.

22 Ibld.

$2=$ Denis Mack Smith, op, clt., p. 226.

24Robert Hilchels, op.cit., p. 271.

25Wayl and H1lton-Young, ap, cit., P. 62. 
2૯Ibld., pp. 65-66.

3 Ibid., p. 66 .

zoIbld.

2PIvanoe Bonomi, From Soclalism to Fascism (London: $M$. Hopkinson and Co. 1924) 177 .

${ }^{\circ} \mathrm{Cec} 11$ J. S. Sprigge, The Development of Modern Italy

(New Haven, Yale University Press, 1944) 107.

32 Ibid.

salpid., P. 108.

osibid.

34Ibid., p. 116.

ssibid., p. 120.

s-Wayland Hll ton-Young, op, elt,, p. 78.

3 Ibla.

sopletro Nennl, Ten Years of Tyranny in Italy (London: George Allen and Unwin Ltd., 1932) 42.

swayland HIlton-Young, ope clt., p. 78.

${ }^{40}$ Cecil J. S. Sprigge, gp. Eit,, p. 141.

41 Ibid.

42 I vanoe Bonomi, op. elt, p. 16-18.

${ }^{40}$ Cecil J. S. Sprigge, op, cit., p. 142.

4Wayl and Hil ton-Young, op, cit., p. 83.

${ }^{45 C e c i l l ~ J . ~ S . ~ S p r l g g e, ~ o p, ~ c i t ., ~ p . ~} 159$.

4tIbid,

$4>$ Ibld.

48Ibid., pp. 159-161.

CHAPTER V

'Pletro Nenni, op, cit., pp. 77-80.

Ibld., pp. 80-81. 
Ibld., p. 78.

4 Ibld., p. 46.

Ibid., p. 47.

sibid., p. 48.

DDenis Mack Smith, op. cit., pp. 329-355.

Ibla.

IIbld.

10 Ibld., pp. 345-346.

1 Ibid., pp. 342-343.

1 Wayl and Hill ton-Young, op, clt,, p. 127.

3 Iplde, p. 131.

14 Ibid., pp. 127-129. 


\section{BIBLIOGRAPHY}

Arendt, Hannah. The Orlains of Totalltarlanlsm. New York: Harcourt, Brace and Co., 1951.

Bonoml, Ivanoe. From Soclallsm to Eascism. London: M. Hopk inson and Co., 1924.

Croce, Benedetto. A History of Italy: 1870-1915. Oxford: Clarendon Press, 1929.

Duverger, Maurlce. Political Parties: Their Organization and Activity in the Modern State. London: Methuen and Co.. Ltd., 1954.

Friedrich, Carl J. Constitutional Government and Democracy: Theory and Practlce in Europe and Amer Lea. New York: GInn and Company, 1950.

Gay, Peter. The Dilemma of Demecratle Sociallsm. New York: Columbia University Press, 1952.

Glolltti. Glovannl. Memories of My Life. Monza: Garzant Editor, 1945.

Hilton-Young, Wayland. The Itallan Left. London: Longman's Green and Co., 1949.

Hughes, Stuart H. The United States and Italy. Cambridge: Harvard Unlversity Press, 1953.

Kogan, Norman. Italy and the Allles. Cambridge: Harvard University Press, 1956.

Marchetti, Livio. The Ecenomic Revival of Italy. Turin: Editrice Torinese, 1919.

Michels, Robert. A critical study of the Itallan Sociallst Mevement. Firenze: LeVoce, 1926.

Nenni, Pletro. Ten Years of Tyranny in Italy. London: George Allen and Unwin, Ltd., 1932.

Ross1. Angelo. A Comunlst Party in Actlon. New Haven: Yale University Press, 1949. 
Schattschnelder, E. E. Party Government. New York: Rl nehart and Co., Inc., 1942.

Seton-Watson, Christopher. Italy from Ilberalism to Fascism: 1870-1925. London: Butler and Tanner Ltd., 1967.

Sforza, Carlo. Contemporary Italy. New York: E. P. Dutton and Co., Inc., 1944.

Smlth, Denls Mack. Italy. Ann Arbor: Unlverslty of Mlchlgan Press, 1959.

Sprigge, Cecil J. S. The Development of Modern Italy. New Haven: Yale University Press, 1944.

Sturmthal, Adolph F. The Tragedy of European Labor. 1918-1939. New York: Columbia Unlversity Press, 1943. 